\title{
Pacific decadal climate variability: indices, patterns and tropical- extratropical interactions
}

\author{
Benjamin J. Henley
}

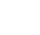

Address: School of Earth Sciences, University of Melbourne, Australia Australian Research Council Centre of Excellence for Climate System Science (ARCCSS) 8

Corresponding email address: bhenley@unimelb.edu.au

$$
\text { Submitted to: Global and Planetary Change }
$$
Keywords: Interdecadal Pacific Oscillation, IPO, Pacific Decadal Oscillation, PDO, Pacific Decadal Variability, PDV

Highlights:

- Review of patterns and indices of PDV using observations and palaeoclimate data

- IPO, PDO and SPDO related to, affected by, but distinct from ENSO in extratropics

- New stochastic tool provides probabilistic estimate of recent PDV state

- Bi-hemispheric tropical-extratropical interactions might explain coherence IPO/PDO

- Intense research focus needed on PDV observations, palaeoclimate and modelling 


\begin{abstract}
Pacific decadal variability (PDV) plays a critical role in the climate system. Here I present a review of indices and patterns of decadal climate variability in the Pacific from observations and palaeoclimate reconstructions. I examine the spatial characteristics of Pacific sea surface temperature variability and the metrics used to track observations of PDV. I find commonalities between the PDV patterns, the Interdecadal Pacific Oscillation (IPO) and its North and South Pacific counterparts, the Pacific Decadal and South Pacific Decadal Oscillations (PDO and SPDO). I present a tool to provide probabilistic quantification of the recent state of the IPO, and use the tool to provide reliable estimates of IPO state up to 2 years prior to the present. The tool indicates a probability of $80-90 \%$ that the IPO remained in its negative state until 2014-2015. I review palaeoclimate reconstructions of the IPO and PDO, and outline advances and challenges in our pre-instrumental understanding of PDV. I draw attention to a Pacific-wide tropical-extratropical mechanism that suggests that the cool and warm phases of PDV are not driven by tropical or extratropical variability alone, but are instead the result of continuous tropical-extratropical interactions on decadal timescales. I conclude by noting the persistent uncertainties and emphasising the need to better understand decadal variability through continual improvements in observations, an expansion of palaeoclimate exploration and data collection and renewed efforts in model development.
\end{abstract}

\title{
Table of Contents
}

1. Introduction 3

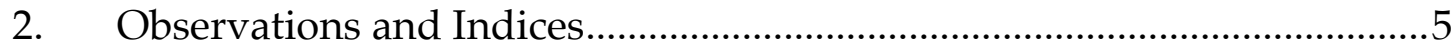

2.1. Patterns and timeseries of Pacific decadal variability ......................................... 5

2.2. Influence of PDV on global surface temperature …............................................ 7

2.3. A tool to quantify the PDV state in the recent past .......................................... 8

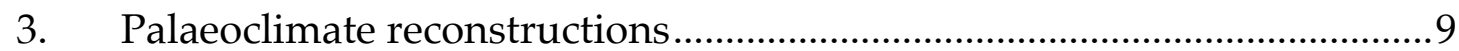

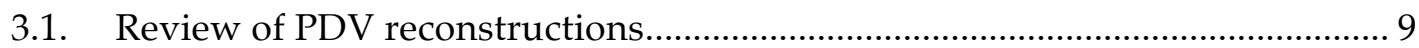

3.2. Comparison of PDV reconstructions ............................................................. 13

4. Tropical-extratropical interactions …...................................................... 15

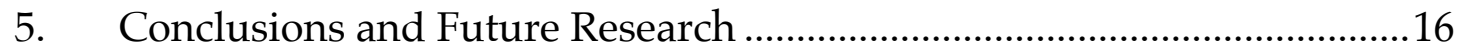




\section{Introduction}

Variability on decadal timescales is critically important for planning. It is the intermediate timescale nestled between the better understood and more predictable interannual climate variability such as that associated with the El Niño Southern Oscillation (ENSO) and North Atlantic Oscillation (NAO) and the centennial and longer timescale changes due to external factors such as rising greenhouse gas emissions. Decadal-scale changes in the mean climate state are near enough to pose tangible risks to existing critical infrastructure, but long enough to be a significant challenge to climate prediction (Meehl et al. 2009). These challenges are due primarily to the limitations of an under-observed climate and its chaotic natural variability sensitive to initial conditions.

Decadal variations in the risk of extreme episodes such as floods, droughts and heatwaves on decadal timescales have implications for risk assessment, with direct relevance to the insurance industry, the value of public and private assets and the safety of engineered materials and structures which have typically been designed under the assumption of risk stationarity. Agricultural and water supply systems are typically designed to withstand seasonal to interannual variability. But hydrological persistence on decadal timescales can pose additional unplanned threats to human and natural systems. Near term decadal prediction is now an intrinsic part of climate change projection and has a prominent chapter in the regular Assessment Reports (e.g. AR5) of the Intergovernmental Panel on Climate Change (IPCC, Kirtman et al. 2013).

Natural internal patterns of Pacific Decadal Variability (PDV), particularly the Interdecadal Pacific Oscillation (IPO, Folland et al. 1999; Power et al. 1999), the closely-related Pacific Decadal Oscillation (PDO, Mantua et al. 1997) and the Atlantic Multidecadal Oscillation (AMO, Knight et al. 2005) have been implicated in periods of acceleration and slowdown in the rate of global warming at the surface in the post-industrial period (England et al. 2014; Maher et al. 2014; Kosaka \& Xie 2013; Kosaka \& Xie 2016; Fyfe et al. 2016; Crowley et al. 2014). These patterns are also responsible for coherent and persistent hydroclimatic impacts globally. The uncertainty in the trajectory of global mean surface temperature in the coming 1-2 decades due to internal climate variability is higher than the uncertainty from emissions scenarios (Hawkins \& Sutton 2009). This places decadal variability and decadal prediction firmly in the spotlight.

The El Niño Southern Oscillation (ENSO) is at the heart of the variability in the Earth's climate system. ENSO is the primary driver of interannual climate variability and is responsible for widespread impacts on global weather (Allan 2000). The Interdecadal Pacific Oscillation (IPO) and the Pacific Decadal Oscillation (PDO) are decadally-varying climate patterns in the Pacific. The terminology of these decadal patterns can be the subject of some confusion. One particular point of confusion is the difference between a pattern and a climate mechanism. The false assumption that the PDO and IPO are known mechanisms leads people to question whether they are "real". The IPO and PDO are SST patterns, and are therefore 
most certainly real. The American Meteorological Society (AMS) maintains an online glossary (glossary.ametsoc.org) which lists both the PDO and the IPO as patterns in SST. The PDO is the leading pattern of decadal to multidecadal variability in North Pacific sea surface temperature North Pacific SST data (Mantua et al. 1997; Zhang et al. 1997; Mantua \& Hare 2002). The IPO is a broader SST pattern associated with Pacific-wide SSTs (S Power et al. 1999; Folland et al. 1999; Henley et al. 2015).

The IPO and PDO are closely related to ENSO, and most dynamical studies find that these decadal patterns are likely induced, at least partially, by tropical variability associated with ENSO, along with stochastic atmospheric forcing (Newman et al. 2016). The South Pacific complement of the PDO has been termed the South Pacific Decadal Oscillation (SPDO, Chen \& Wallace 2015; Shakun \& Shaman 2009). This article refers to the patterns of the IPO, PDO and SPDO collectively as PDV patterns.

A review of the mechanisms of the PDO by Newman et al. (2016) underlined findings that the PDO is an aggregated pattern of a number of physical ocean and atmosphere processes, rather than the fingerprint of a single dynamical mechanism in the North Pacific. Liu (2012) reviewed the dynamics of decadal climate mechanisms in the Pacific and Atlantic, highlighting the importance of stochastic forcing and Rossby wave propagation in the extratropics and calling for further targeted studies using coupled ocean-atmosphere models. The study by Meehl \& Hu (2006) provided some of the first comprehensive demonstrations of IPO mechanisms. The review of ENSO by Wang et al. (2012) discussed aspects of Pacific decadal variability and identified uncertainties in the mechanisms and preferred timescales of variability.

In this review, I focus on observational and palaeoclimate indices of PDV and draw specific attention to a plausible mechanism for quasi-symmetry in PDV through tropical-extratropical interactions. I aim for a concise summary of common understanding across studies that focus on the IPO and PDO. Considering the degree of symmetry between North and South Pacific patterns, I consider the possibility that the component of the PDO pattern driven by tropical variability is part of the inter-hemispheric quasi-symmetrical IPO pattern. I review a mechanism driven primarily by ocean-atmosphere interactions between the tropics and extratropics, as described by Farneti et al. (2014). In agreement with Newman et al. (2016), I consider atmospheric forcing and regional ocean currents to influence the North and South Pacific PDO and SPDO patterns largely independently, giving rise to the non-symmetrical aspects of the North and South Pacific Patterns. I note also the identification of alternative mechanisms such as the influence of aerosols on decadal mechanisms (Smith et al. 2016). I find agreement between studies that have focussed on the PDO and IPO and I encourage further momentum towards a focussed global effort on monitoring, modelling and prediction of decadal variability.

This review is organised as follows. In section 2 I outline the major observed patterns of variability in the Pacific, and describe the indices used to track these PDV patterns. In section 
3 I review our understanding of past PDV by examining palaeoclimate reconstructions of the IPO and PDO, comparing their temporal evolution and frequency domain behaviour. In section 4, I explore a Pacific-wide extension of the dynamical process presented by Farneti et al. (2014). I reason that despite significant advances in recent decades, we currently lack sufficient data and dynamical evidence to conclusively reject the major proposed mechanisms, recommending that a number of causal mechanistic arrangements remain plausible. I conclude in section 5 by emphasising the need to better understand decadal variability. This can be achieved through sustained continuous observations, continual improvements in observational networks, renewed efforts in model development and experiments targeting decadal variability, and an expansion of palaeoclimate exploration and data collection, particularly in the Southern Hemisphere.

\section{Observations and Indices}

\subsection{Patterns and timeseries of Pacific decadal variability}

As the primary driver of interannual climate variability globally, the El Niño Southern Oscillation (ENSO) has been the subject of focussed observation and modelling for several decades. The El Niño and La Niña phases of ENSO occur irregularly at a period of around 2-7 years. In addition to these interannual variations associated with ENSO, decadal-scale variations in Pacific climate, or PDV, have been identified.

Figure 1 summarises the major patterns of global sea surface temperature (SST) variability (using ERSSTv4, Huang et al. 2015). The linear trend in SST for 1900-2015 in panel (a) reveals unequivocal and widespread warming of the ocean surface in the post-industrial era. The trend is between $0-0.1^{\circ} \mathrm{C}$ per decade over almost all of the ocean surface over the full period. Note that more rapid warming has occurred in the second half of the observed period (not shown). Warming across much of the Pacific is less than in the Atlantic, Indian and Southern Oceans, as noted by Power et al. (2016). The spectral characteristics of global SST are compared in panels $(b-d)$. The average spectral bandpower in each grid cell for the 2-7 year and 7-30 year frequency bands is computed from the power spectral density curve. The upper limit of 30 years is selected to be safely less than the period corresponding to the Nyquist frequency, which is the minimum rate at which a signal can be resolved without introducing aliasing. The global dominance of ENSO at interannual timescales is strongly apparent in the high 2-7 year variance in the eastern and central equatorial Pacific (panel b), with some areas of high 2-7 year variance apparent in the midlatitudes, particularly in the northwest Pacific. Variance in the 7-30 year frequency band is high across much of the central Pacific and in the North Pacific, with the variance maximum in the North Pacific further to the east than in the 2-7 year band. The ratio of the 7-30 year and 2-7 year frequency bands reveals a dominant pattern in the western Pacific and eastern Indian Ocean around the maritime continent, as well as a strong extension along the South Pacific Convergence Zone (SPCZ). The SPCZ is an expansive convective cloud band extending in a southeasterly direction from the western Pacific (Vincent 1994). The high ratio of the bands here reflects both the relatively low 
variance in the interannual band and the decadal variability in the location of the SPCZ. The SPCZ location is understood to be modulated by the PDV mean state (Folland et al. 2002; Salinger et al. 2014). It is noted that the AMO, which has dominant periodicities at 20 years and 45-65 years (Chylek et al. 2011; Chylek et al. 2012) is only partially covered by the frequencies represented here. Similar results are obtained when the analysis is repeated using the HadISST1 data (Figure S1, Supplementary Material).

The pattern of decadal to multidecadal sea surface temperature (SST) variability in the North Pacific has been termed the Pacific Decadal Oscillation (PDO) (Mantua et al. 1997; Mantua \& Hare 2002). The Interdecadal Pacific Oscillation (IPO) is characterised by a Pacific-wide decadally varying SST pattern (S. Power et al. 1999; Folland et al. 1999; Folland et al. 2002; Parker et al. 2007; Christensen et al. 2013). The South Pacific counterpart of the PDO has also been documented, and termed the South Pacific Decadal Oscillation (SPDO, Chen \& Wallace 2015; Shakun \& Shaman 2009). I note however that direct comparison between hemispheric patterns is influenced by the differing distribution of observations in time and space, with a higher number of observations in the northern hemisphere than the southern hemisphere, particularly prior to the satellite era.

Previous studies have used a variety of datasets and methods to calculate time series and spatial patterns of the IPO and PDO, as summarised in Table 1 (adapted from Henley et al. 2015). Most have used Principal Component Analysis (PCA) and related techniques to define PDV patterns. The method introduced by Henley et al. (2015) uses a linear combination of mean SST in three large boxes in the Pacific.

Figure 2 compares spatial patterns and timeseries of the three major PDV patterns and Niño 3.4 using ERSSTv4. Both the unsmoothed and smoothed (13-year Chebyshev low-pass filtered) versions of the timeseries are shown. For the IPO, the Tripole Index (TPI) of Henley et al. (2015) is shown (calculated as described in Table 1). The PDO is the first principal component (PC) of North Pacific SST poleward of $20^{\circ} \mathrm{N}$ (Mantua et al. 1997), the SPDO is the South Pacific counterpart, the first PC of South Pacific SST poleward of $20^{\circ} \mathrm{S}$ (Chen \& Wallace 2015). Note that poleward boundaries of $60^{\circ}$ and $70^{\circ}$ in both hemispheres have been used for PDO and SPDO indices (Chen \& Wallace 2015; Henley et al. 2015), however this has little influence on the resulting patterns and timeseries. Here I use $70^{\circ} \mathrm{N}$ and $70^{\circ} \mathrm{S}$. The Niño 3.4 index is the mean SST in the central Pacific $\left(5^{\circ} \mathrm{S}\right.$ to $\left.5^{\circ} \mathrm{N}, 170^{\circ} \mathrm{W}-120^{\circ} \mathrm{W}\right)$. The patterns in panels $\mathrm{a}, \mathrm{c}$, e and $\mathrm{g}$ are obtained by regression of global SST onto the filtered timeseries.

The IPO pattern has hemispheric quasi-symmetry and high variance in large regions in both the western North and South Pacific. The PDO and SPDO have dominant variance in their respective hemispheres, particularly the PDO. There are strong similarities between all four patterns, especially between the IPO and Nino3.4, as noted by Newman et al. (2016), and also the SPDO and Niño3.4. However, the dominance of the tropical variance over the extratropical variance is only strongly apparent for Niño 3.4. The other patterns all have relatively much stronger extratropical variability. 
Turning to the temporal evolution of the patterns in panels $\mathrm{b}, \mathrm{d}, \mathrm{f}$ and $\mathrm{h}$, the timing of the decadal variations is strikingly similar for all three PDV timeseries, with the well-established twentieth century shifts apparent around 1945, 1977 and 1999. The fact that the major PDV phase shifts are shared by the PDO and SPDO reveals strong hemispheric symmetry and is suggestive of a common element for these major shifts despite their data regions having no overlap. The decadal Niño 3.4 timeseries has similar timings for these shifts, but has additional zero crossings and substantially shorter durations between decadal oscillations. The PDV timeseries have periods of 30 or more years of persistent PDV phase, but this is not evident in the Niño 3.4 series. Although there is decadal variability in the Niño 3.4 region, the PDV timeseries exhibit significantly higher multidecadal persistence due to their incorporation of extratropical variability. Together, these observations suggest that the PDO and SPDO could be viewed as being part of a larger hemispherically symmetric PDV pattern. This pattern is strongly related to, but has higher memory on decadal timescales than, tropical variability alone. Therefore, diverging from the suggestion of Westra et al. (2015) that low-frequency ENSO and the IPO are equivalent, yet still acknowledging the similarities and known dynamical links between PDV and ENSO (as discussed in section 4), I find sufficient distinction between the spatial patterns and timeseries at decadal timescales to warrant the independence and use of the PDV series. The smoothed Niño 3.4 index is not a sufficient substitute for indices of Pacific decadal variability.

\subsection{Influence of PDV on global surface temperature}

A critically-important influence of PDV identified in recent years is its association with global mean surface temperature (GMST) variations (England et al. 2014; Maher et al. 2014; Kosaka \& Xie 2013; Kosaka \& Xie 2016; Fyfe et al. 2016; Meehl, Hu, Santer, et al. 2016; Henley \& King 2017). Here I update the GMST and PDV timeseries by England et al. (2014) to include recent data and reorient the polarity of highlighted areas to designate the presence of positive phases (Figure 3). Periods of accelerated warming are associated with PDV positive phases (1925-1944, 1977-1998) and periods of slowdown in warming are associated with PDV negative phases (1945-1976, 1999-recent). The expected cooling effect of the negative phase from 1907-1926 is not apparent, which could be due to the uncertainty in IPO phase in this early data, or other non-PDV factors influencing global temperatures at this time. The record GMST years in 2015 and 2016 appear to indicate early signs of a resumption of accelerated warming. Although initialised decadal predictions are suggestive of an IPO positive transition (Meehl, Hu \& Teng 2016), the accurate prediction of phase changes with multi-year lead times remains a research challenge. DelSole (2017) provides a review of decadal prediction of temperature, and points toward the additional use of simpler empirical models in decadal prediction. Several large research programs and studies are also focussed on decadal prediction and predictability (Meehl et al. 2014; Boer et al. 2016; Marotzke et al. 2016). Decadal prediction was the subject of a chapter in the fifth assessment report by the IPCC (Kirtman et al. 2013). Given these existing reviews, in the next section I focus on the estimation of the state of PDV in the recent past. 
254

One of the challenges of tracking low-frequency phenomena is the question of the current state. Low-pass filters require windowing, which induces end effects at the start and termination of a time series. Common methods for handling end points include reflection or reduction of the filter order near the end points, but these induce end effects and can have spurious influences. In the case of a 13 year window (W), using annual data, for example, the last (and first) 6 years of the resulting smoothed series are influenced by reduced data available at the end point. A smoothed timeseries dated at the centre of the filter can have its most recent unaltered data point precisely 6 years prior to the last unfiltered data point. Typically, the most recent $\sim \mathrm{W} / 2$ years of data are removed, or an alternative end-point estimate is used such as reflection, for which there is no likely physical justification. There is a continuum at the end points, whereby the state of the smoothed series is gradually less certain as the timeseries steps closer to the last data point, at which point it is most uncertain. Here I quantify this uncertainty using the TPI as an example.

I use an autoregressive (AR) model to simulate non-dynamically informed naïve future trajectories of the IPO, conditioned on the previous values. I emphasise that the aim here is only to provide an estimate of the recent state of the IPO, rather than any future state. I first fit a fifth-order autoregressive (AR5) process to the monthly TPI data. I then generate an ensemble of stochastic replicates of future unfiltered TPI, after initialising the model with the last 5 months of TPI data. The model order is optimised using Schwarz's Bayesian Criterion (Schwarz 1978), an established formal statistical method of finding an optimum model given varying numbers of parameters and goodness of fit. Figure 4a shows the timeseries of unfiltered TPI data from 1990-2017, and the ensemble of low-pass filtered TPI. The ensemble of smoothed TPI series is obtained by stitching stochastic future trajectories from the initialised autoregressive process onto the past observed values and applying the low pass filter to smooth across the past-future boundary. This allows the filtered TPI to be computed up to the current data point, and estimates of the uncertainty of the recent TPI to be made under the assumption of AR red noise. Figure $4 \mathrm{~b}$ shows the Brier skill score (BSS) for the IPO estimation tool, at lags relative to the current year. Positive values in BSS represent skill in the probability estimate above random chance (noting the influence of serial dependence; Wilks, 2010). Skill is computed for the period 1900-2000, during which the IPO state is known. Figure 4c shows the probability of IPO states for the period 2006-2017 using the IPO state estimation tool, conditioned on the most recent TPI data available (Apr, 2017) at the time of writing.

Most assessments of the IPO state truncate estimates of the low frequency series at around 710 years prior to the most recent data. The tool described here provides more information (data is available at www.esrl.noaa.gov/psd/data/timeseries/IPOTPI). It shows that, under the assumption of red-noise, there is an $80-90 \%$ probability that the IPO remained in its negative state until 2014-2015, after which point the probability of a positive IPO state is increasing. The tool provides a methodology for estimating the state of the IPO 
probabilistically, and in doing so raises the confidence of our knowledge of the recent 1-6 years of the IPO. Better knowledge of the state of climate modes is likely to have benefits for the estimation of risk to water resources (Henley et al. 2013) and robust planning in an uncertain climate (Mortazavi-Naeini et al. 2015).

\section{Palaeoclimate reconstructions}

\subsection{Review of PDV reconstructions}

Instrumental PDV indices exhibit significant decadal-to-multidecadal variability. However, the brevity of the instrumental record relative to this decadal-scale variability leads to a high degree of uncertainty in the long-term behaviour of PDV. A better understanding of the frequency preference of PDV is needed. Since the early 2000s, numerous studies have sought additional insight into the pre-instrumental temporal evolution and frequency domain nature of PDV (primarily the IPO, PDO and smoothed ENSO) using palaeoclimate data. This section outlines and compares these reconstructions, extending the overview by Henley (2012).

Biondi et al. (2001) used 189 cores from 99 trees from 6 sites in Southern California (USA) and northern Baja California (Mexico) $\left(31.0^{\circ}-34.6^{\circ} \mathrm{N}, 115.5^{\circ}-119.4^{\circ} \mathrm{W}\right)$ to develop a PDO reconstruction back to 1661 . They had previously found that tree ring records from this region were better correlated with the PDO than ENSO. The species used were Jeffrey pine (Pinus jeffreyi) and big-cone Douglas fir (Pseudotsuga macrocarpa). They then performed a multivariate regression using as predictors the lag-one, concurrent, and lead-one values of the first EOF of the six unsmoothed precipitation-sensitive chronologies. Two 30 year periods of validation data were found to have correlations of 0.6-0.7 between the instrumental and reconstructed PDO. They also found good spectral coherence between their instrumental and proxy record, and a bidecadal frequency (period of around 17-28 years) for the PDO. They found a weakening of the bidecadal signal in the period 1760-1840, with the lower frequencies being restricted to the 20th century. Biondi et al. (2001) mention that although a 22-yr periodicity is also shown by solar activity, their PDO reconstruction showed no correlation with the Sun's radiative forcing at either annual or decadal timescales. This led them to suggest that internal dynamics of the coupled ocean-atmosphere system have greater dendroclimatic significance than solar cycles at their study sites. Biondi et al. (2001) suggested that an expansion of their analysis using different networks and multiple proxies should be conducted to verify and extend their findings.

Gedalof \& Smith (2001) compiled six tree ring-width chronologies since 1600 from stands of mountain hemlock (Tsuga mertensiana) from southern Oregon to the Kenai Peninsula, Alaska $\left(42.6^{\circ}-60.1^{\circ} \mathrm{N}, 122.1^{\circ}-149.0^{\circ} \mathrm{W}\right)$, further north than the study by Biondi et al. (2001). Gedalof \& Smith (2001) noted that while summer temperature is the dominant factor influencing the annual radial growth of mountain hemlock, at lower latitudes the growth was also sensitive to precipitation. They used Factor Analysis to combine the six chronologies. The leading eigenvector from the Factor Analysis explained $44 \%$ of the variance in ring-width and a linear 
regression against the PDO provided their PDO reconstruction dated back to 1600. Gedalof \& Smith (2001) used wavelet analysis to analyse the evolution of the PDO, and in contrast to Biondi et al. (2001), they found that all of the interdecadal energy (30-70 years) is confined to the pre-1840 portion of the series, with nearly all of the interannual energy $(<8$ years) occurring between 1840 and 1930. They found variability at 10-20 years present throughout the reconstruction. This suggests that the PDO is more likely to fluctuate on a decadal timescale, but can also exhibit a wide range of shorter and longer period durations.

D'Arrigo et al. (2001) used tree ring density and width data, also from sites further north than Biondi et al. (2001), including temperature sensitive sites in coastal Alaska $\left(60.4^{\circ} \mathrm{N}, 145.4^{\circ} \mathrm{W}\right)$ and the Pacific Northwest $\left(57.0^{\circ} \mathrm{N}, 135.1^{\circ} \mathrm{W}\right)$ as well as a precipitation sensitive site on the subtropical North American coast $\left(45.0^{\circ} \mathrm{N}, 121.0^{\circ} \mathrm{W}\right)$ and two drought index sites in Mexico. After first screening the datasets for sites with a strong correlation with the PDO index of Mantua et al. (1997), D' Arrigo et al. (2001) produced a tree ring/PDO model using Principal Component Regression (PCR), after Cook et al. (1999). D'Arrigo et al. (2001) produced two PDO reconstructions extending back to 1700 and 1790, using different sites in the makeup of the indices and accounting for 53\% and $44 \%$ of the variance in the instrumental PDO in their overlapping period. Again, unlike Biondi et al. (2001), the D'Arrigo et al. (2001) reconstructions suggested less pronounced PDO interdecadal variability since the mid-1800s. D'Arrigo et al. (2001) found significant (5\% level) spectral power at periods of 25-50 years and around 2-3 years.

MacDonald \& Case (2005) produced a millennium length PDO reconstruction covering the period 993-1996 CE using tree rings of both living and dead Limber pine (Pinus flexilis) specimens from the southern and northern areas of previous studies (southern California $\left(34.1^{\circ} \mathrm{N}, 116.5^{\circ} \mathrm{W}\right)$ and Alberta in western Canada $\left(52.0^{\circ} \mathrm{N}, 116.5^{\circ} \mathrm{W}\right)$ ). The sites from these two areas are at opposite ends of the North American precipitation-PDO impact dipole (a positive PDO leads to higher precipitation to the south and decreased precipitation to the north). They used the post-1940 PDO index to calibrate a multiple linear regression model between the ring widths and the PDO. Their index agreed reasonably well with that of Biondi et al. (2001) ( $r=0.57)$, but fairly poorly with the reconstruction of Gedalof \& Smith (2001) ( $r=0.19)$. The first 300 years (the medieval period) of the MacDonald \& Case (2005) PDO index exhibits a pronounced negative PDO (993-1300 CE), with other significant century-scale shifts apparent in their index. This indicates that the variability of the PDO has possibly been unstable over previous centuries. Using wavelet analysis on a detrended form of the index they found evidence of 50-70 year periodicity of the PDO, varying significantly in strength over the reconstruction period. The 50-70 year frequency band was earlier reported by Minobe (1997). Hidalgo et al. (2001) and MacDonald \& Case (2005) suggested that the relative sensitivity of different tree species to persistent drought could be a reason for the discrepancy between the prominence of the 50-70 year band in their study and the 12-28 year frequency band in earlier studies. 
D'Arrigo \& Wilson (2006) produced a four century (1565-1988 CE) PDO reconstruction using tree ring data from Asia, following evidence of interaction between the atmosphere over Asia and decadal Pacific SST variability (Minobe 1997; Frauenfeld \& Davis 2002; Schneider \& Cornuelle 2005). They used data from 17 sites in east Asia in their PDO reconstruction. This subset was chosen from an initial set of 70 sites, based on their correlation with the PDO over 1900-1988 during March-May (just prior to the growing season) over a wide geographical area. Their domain was from as far north as approximately $66.5^{\circ} \mathrm{N}$ in northern Russia and as far south as $27.5^{\circ} \mathrm{N}$ in Bhutan, with several sites in Mongolia and Japan. D'Arrigo \& Wilson (2006) used PCR, and checked signal fidelity using a nested approach, removing the shortest signal and recomputing statistics, then repeating. They concluded that their reconstruction provides useful information about the Asian expression of the PDO at both interannual and decadal time scales. D'Arrigo \& Wilson (2006) reported spectral analysis results that revealed peaks at 2-3 and 23 years, with some lower frequency modes, suggesting some commonality with the work of Biondi et al. (2001) (17-28 years) and D'Arrigo et al. (2001) (25-50 years). D'Arrigo \& Wilson (2006) discussed broader linkages between the PDO and atmospheric variables, the North Pacific Index (NPI), volcanic events, a coral record from the Indian Ocean and the Asian monsoon. They suggested that to minimise disagreement between regional PDV signals, future attempts at reconstructing the PDO may be optimised by including both Asian and North American data.

Shen et al. (2006) published a 530-year PDO reconstruction from 1470 using categorical documentary drought/flood index records (a five-grade category index), from 28 of 58 available regions in eastern China $\left(22-40^{\circ} \mathrm{N}, 110-122^{\circ} \mathrm{E}\right)$. The indices were derived from Chinese historical documents (such as precipitation records and descriptions) by the China Meteorological Administration (Zhang et al. 2003). Shen et al. (2006) used the 1925-1998 PDO index of (Mantua et al. 1997) for calibration, and produced their PDO reconstruction using a 5-component Partial Least Squares (PLS) regression model. Their reconstruction explained $78 \%$ of the instrumental PDO variance, and spectral analysis showed a broad range of frequency bands: 11-12, 23-28, 35-45, 50-70 and 75-115 year being statistically significant at the $5 \%$ or $10 \%$ level. The prominence of frequency bands fluctuated in spectral power throughout the reconstruction period, with the 50-70 year band apparently appearing only since 1850 . Shen et al. (2006) suggested that lunar-solar tidal forcing contributed towards the pre-1850 oscillation of the PDO, and that since 1850 the dominant mode of oscillations of the PDO may have been modulated by global warming caused by greenhouse gas forcing.

Linsley et al. (2008) used annual average oxygen isotope (d18O) time series from five Porites lutea coral cores from Fiji and Tonga $\left(16.8^{\circ}-21.0^{\circ} \mathrm{S}, 179.2^{\circ}-174.7^{\circ} \mathrm{W}\right)$ to produce their Fiji-Tonga Interdecadal-Decadal Pacific Oscillation (F-T IDPO) index of low frequency Pacific climate variability back to 1650 . They exploited the expression of the IPO phenomenon on the low frequency displacement of the SPCZ in coral isotopes in the South Pacific Convergence Zone (SPCZ) salinity front region. The salinity front occurs due to oceanic circulation patterns and a precipitation-evaporation imbalance, as identified by Gouriou \& Delcroix (2002). Fresher and warmer waters of the western Pacific lie to the west, and cooler, saltier waters lie to the 
east of the salinity front. Coral $\mathrm{d} 18 \mathrm{O}$ isotopes record the variation in these changes, with saltier water producing higher coral $\mathrm{d} 18 \mathrm{O}$ values. The location of the SPCZ and the associated salinity front has been linked to ENSO (Gouriou \& Delcroix 2002; Juillet-Leclerc et al. 2006; Linsley et al. 2006) and IPO variability (Folland et al. 2002). Linsley et al. (2008) used Singular Spectrum Analysis to resolve PDV in the 9-55 year band and computed their F-T IDPO index as the arithmetic mean of bandpass filtered d18O records. Their F-T IDPO index (from data south of the equator) was found to be anticorrelated (correlations of -0.41 and 0.51) and synchronous with two coral $\mathrm{d} 18 \mathrm{O}$ interdecadal-decadal components from equatorial Pacific coral records, at Maiana and Palmyra, revealing a broader trend and providing some insight into oceanic mechanisms. Although extracted from data independent of the instrumental SST-based IPO index, the indices were highly correlated and in strong agreement regarding the timing of phase shifts. Linsley et al. (2008) noted distinct reductions in the amplitude of the interdecadal-decadal signal around 1685-1705 and 1740-1755 CE. Despite this apparent indication of the presence of 15-20 year neutral phases of the IPO, the F$\mathrm{T}$ IDPO index also showed that a relatively regular progression of positive and negative IPO phases have occurred since 1650 in the SPCZ region, with a mean frequency of around 20 years and variance peaks near 11 and 35 years. Linsley et al. (2008) explained that this implied some degree of predictability in the IPO phenomenon and its proposed modulation of ENSO. A composite of South Pacific corals from Fiji, Tonga and Rarotonga back to 1791 by Linsley et al. (2015) revealed similar results, with relationships with the PDO and upper ocean heat content in the instrumental period. They found that decadal-scale changes in the South Pacific are a semiregular phenomenon with a mean period of around 25 years.

Verdon \& Franks (2006) identified step changes in both IPO and PDO palaeoclimate and instrumental data sources. Their approach used the non-parametric Mann-Whitney U-test to identify differences between two halves of data in a 30-year moving window (Mauget 2003) in the reconstructions of (Biondi et al. 2001; D'Arrigo et al. 2001; Gedalof et al. 2002; MacDonald \& Case 2005) and the coral record of (Linsley et al. 2000) at Raratonga. Verdon \& Franks (2006) used the records to subjectively estimate the timing of PDO positive and negative phases, forming a composite categorical phase change PDO index for the period 1662-1992.

Mann et al. (2009) reconstructed global surface temperature fields over the period 500-2000 CE using a multiproxy palaeoclimate network of 1138 records. Their dataset was made up of 1036 tree-ring records, 3 marine sediment series, 14 speleothem series, 19 lacustrine series, 32 ice core series, 15 marine coral series and 19 historical documentary series. They used the regularised expectation maximisation (RegEM) climate field reconstruction (CFR) procedure of (Schneider 2001; Mann et al. 2007) where high-frequency (period $<20$ years) and lowfrequency (period $>20$ years) components of the reconstruction are calibrated separately. The regional average temperature in region associated with the PDO $(22.5 \mathrm{~N}-57.5 \mathrm{~N}, 152.5 \mathrm{E}-$ $132.5 \mathrm{~W})$ was extracted from the surface temperature field reconstruction for the period 5002000 to obtain their PDO index. There is a strong resemblance between their global mean temperature series and their PDO index. The authors note that the low value of their 
truncation parameter $\mathrm{K}$ may lead to greater apparent levels of similarity between regions than exists in the true spatial temperature pattern. They acknowledge that this likely leads to their calculated indices, including the PDO, exhibiting an artificially high level of similarity than their true underlying counterparts, particularly prior to 1600 CE (Mann et al. 2009).

The study by McGregor et al. (2010) merged 10 ENSO reconstructions into a unified ENSO proxy (UEP) using PCA to extract and reconstruct the joint features of the component reconstructions. McGregor et al. (2010) smoothed their UEP reconstruction to obtain an estimate of low frequency ENSO variability, finding similarity with the IPO and smoothed PDO indices in the instrumental period. They found an increase in ENSO variance since 1900, which could have been related to reduced signal-to-noise back in time, possibly related to dating uncertainties.

Henley et al. (2011) consolidated the 7 PDO and IPO reconstructions of Biondi et al. (2001), D'Arrigo et al. (2001), Gedalof \& Smith (2001), MacDonald \& Case (2005), D'Arrigo \& Wilson (2006), Shen et al. (2006) and Linsley et al. (2008) to form a combined palaeo IPO index (CPIPO) over the period 1570-2000. They used an objective smoothing procedure to fit low pass filters to individual reconstructions, and combined these filtered series using an averaging scheme that weighted each series to the goodness of fit to instrumental data. They found that over the 440 years of the reconstruction the IPO had a broad frequency range, with a positively skewed distribution of phase durations varying between 3 and 33 years and a mean of 15 years. Similarly to McGregor et al. (2010) an increase in variance was observed since 1900.

Vance et al. (2015) developed a millennium-length reconstruction of the IPO over the period 1000-2003 CE using an annually resolved ice core record from Law Dome in Antarctica. They used two nonlinear multivariate regression methods (decision tree, DT and piecewise linear fit, PLF) to regress ice accumulation and log-transformed sea salt concentration onto the instrumental IPO index. Vance et al. (2015) observed a bias towards more positive IPO (23 positive compared to 13 negative) phases in their reconstruction, particularly prior to around 1200 CE, in contrast to the negative PDO tendency found by MacDonald \& Case (2005) in that period. Vance et al. (2015) also reported an average positive phase duration of 14 years compared to 9 years for the negative phase.

\subsection{Comparison of PDV reconstructions}

Here I compare the temporal and spectral features of the 12 PDV reconstructions reviewed in section 3.1. Figure 5 shows the time series of low-pass reconstructions, for the period 1500$2000 \mathrm{CE}$, shown as shaded anomalies above and below zero, to aid visual comparison of the timing of PDV phase shifts. The unsmoothed time series are also shown where available.

The three major PDV phases in the twentieth century are captured fairly reliably by most of the reconstructions, with the exception of the Mann et al. (2009) PDO index, which is out of phase with all 11 other reconstructions during the negative and positive PDV phases in the 
mid and late twentieth century. It is worth noting that this record was not directly calibrated to an instrumental PDV index, unlike all other reconstructions. There are large discrepancies between the palaeoclimate PDV reconstructions prior to the instrumental period, such that the ensemble could be colloquially termed 'palaeo-spaghetti'. Table 2 shows the Spearman correlations between each pair of reconstructions during their common period of overlap, highlighting statistically significant correlations after adjusting for serial autocorrelation. The strongest correlation is between two of the North American tree ring reconstructions (Biondi et al. 2001; MacDonald \& Case 2005). A total of 112 of the 144 pairwise correlations between smoothed series are below 0.2. The composite reconstructions (Henley et al. 2011; McGregor et al. 2010; Verdon \& Franks 2006) have generally high correlation to the other members, as would be expected. Of the non-composites, the reconstructions of Vance et al. (2015), D'Arrigo et al. (2001) and Biondi et al. (2001) have the highest correlation to the other members. The Mann et al. (2009) index is the only reconstruction with a negative mean correlation with the other members, suggesting that it is not a reliable PDO reconstruction. The reconstructions which extend significantly into the first half of the millennium (MacDonald \& Case 2005; Mann et al. 2009; Vance et al. 2015) bear little or no temporal resemblance to each other.

Figure 6 presents the power density spectra of each of the 12 reconstructions for the period $1700 \mathrm{CE}$ to the most recent data available, using the multi-taper method (MTM, Thomson (1982). First order autoregressive models are fitted to unfiltered data where available, and their spectra added to the figure. The spectra reveal a wide range of frequency characteristics. Most reconstructions reveal very little high frequency variance at periods of $<10$ years, with the possible exceptions of Shen et al. (2006) with peaks 2, 3, 5, and 7-10 years, and D'Arrigo et al. (2001) at < 3 years. For low frequency variability, (Linsley et al. 2008) and (Gedalof \& Smith 2001) have high variance in the 10-15 year band. Multidecadal variability in the 20-50 year band is observed commonly, however consistency in the spectral characteristics of the reconstructions is limited.

In summary, despite significant efforts over the past 20 or more years, palaeoclimate reconstructions don't yet provide a consistent picture of the history of Pacific Decadal Variability in the past millennium, or even in the past 300-400 years when data availability is greatly increased. Discrepancies between reconstructions remain unresolved. These are likely due to: regional or continental limitations of most reconstructions in tandem with the nonstationarity of regional teleconnections (Gallant et al. 2013; Batehup et al. 2015), spectral biases of palaeo archives (Franke et al. 2013) and/or the particularities of reconstruction methods and data treatments. With these discrepancies, despite consistent evidence of preinstrumental teleconnections with regional rainfall (Gergis \& Henley 2016), there is insufficient coherent evidence across reconstructions and regions to be confident in the temporal history or dominant frequencies of PDV in the pre-instrumental period. 


\section{Tropical-extratropical interactions}

Mechanisms of PDV have been widely studied, with several mechanisms proposed to explain PDV and particularly the high decadal variance in the extra-tropical Pacific Ocean. These mechanisms can mostly be grouped into two broad schools of thought with regards to the key driving force: tropical processes and extratropical processes. I note that several mechanisms remain plausible, including the phenomenon of slow westward propagating oceanic Rossby waves in the Pacific which have a time scale near a decade, as highlighted by Meehl \& Hu (2006). It is possible that these Rossby waves interact with the meridional overturning cells. It also appears possible that anthropogenic aerosols have an influence on PDV, with increased aerosol levels potentially causing a negative PDV response and a future decrease in anthropogenic aerosols therefore potentially leading to a positive PDV phase (Smith et al. 2016). I refer the reader to the review of the dynamics of interdecadal climate variability by Liu (2012) for a historical examination of proposed mechanisms.

Here I draw attention to a possible PDV process that couples the tropics and extratropics via both atmospheric and oceanic responses. The process is a bi-hemispheric extension of the mechanism introduced by Farneti et al. (2014). Figure 7 schematically illustrates the mechanism, combining diagrammatic elements adapted from Farneti et al. (2014), Lu et al. (1998) and England et al. (2014). Following the numbered items in the figure, the mechanism of is as follows:

1. Tropical SST anomalies commence in their anomalously cool phase, for example, as observed in the recent negative PDV phase

2. The atmospheric response to these cooler tropical SSTs is a weakening of the thermally-driven rising branch of the Hadley circulation, resulting in a slowdown and equatorward meridional migration of the Hadley cells (the atmospheric 'bridge')

3. This leads to a reduction in the strength of the extratropical trade winds, and the generation of a wind stress curl of anomalous sign to climatology. Note that an equatorward meridional migration of the Hadley cells leads to an increase in the zonal winds within $10^{\circ}$ of the equator, consistent with the findings of England et al. (2014)

4. The Subtropical Gyres (STG) are weakened by these anomalous winds, through reduced Ekman transport and subsequently reduced downwelling, resulting in reduced equatorward mass flux in the subtropical meridional overturning cells (STC) (the oceanic 'tunnel')

5. This reduced STC mass flux also transmits a reduced meridional heat transport and is associated with a reduction in the eastward flowing equatorial undercurrent (EUC, not shown)

6. Equatorial upwelling is therefore reduced, generating a warm SST anomaly at the equator, which is of opposite sign to the original cool SST anomaly. Thus, a negative feedback is induced in the surface layer in the tropics on decadal timescales. 
Most studies to date have sought evidence for a single tropical or extratropical forcing process for PDV, and many studies highlight the role of stochastic atmospheric forcing. Some studies have used simple stochastic characterisations of proposed causal links between ENSO and PDV, however similarly simple hierarchical models that propose a PDV forcing of interannual variability might be equally well validated by observational data. Despite substantial advances in recent decades, we currently lack sufficient data and dynamical evidence to conclusively reject any of the major proposed mechanisms. Statistical verification of a particular model scheme, modelling evidence of isolated mechanisms and the reporting of lead-lag correlations do not guarantee the validity of a causal dynamical relationship. A number of causal mechanistic PDV arrangements therefore remain plausible.

The mechanism outlined here suggests that the cool and warm phases of PDV are not driven by tropical or extratropical variability alone, but are instead the result of coupled and continuous tropical-extratropical interactions on decadal timescales, with a continuum of responses from positive to negative PDV phases, influenced strongly by the tropical influences of ENSO. This interpretation is consistent with the findings of Newman et al. (2016) that there are a number of separate northern and southern hemisphere ocean and atmosphere processes that contribute to differences between the hemispheric responses, such as the Kuroshio current and the Aleutian Low for the northern hemisphere. But, it is plausible that the similarities between northern and southern hemisphere PDV patterns arise from basin-wide quasi-symmetric interactions between the tropics and extratropics, in which the tropics would act as a strong synchronising mechanism for both hemispheres. This mechanism contributes towards an explanation of Pacific-wide coherent patterns of SST variability on decadal timescales.

\section{Conclusions and Future Research}

Decadal variability plays a critical role in the earth's climate system. Given the association between Pacific decadal variability (PDV) and global mean surface temperature (Meehl, Hu, Santer, et al. 2016), and the high contribution of internal variability to projections of near-term climate (Hawkins \& Sutton 2009), PDV is a major potential avenue for constraining climate projections and quantifying non-stationary risks. It is also crucial that we improve our understanding and resilience against severe and persistent multidecadal phenomena such as megadroughts (Ault et al. 2016).

In this article I reviewed the patterns and timeseries of PDV and found strong similarities between the IPO, PDO and SPDO, which all express high variance in the extratropical Pacific Ocean. The major PDV phase shifts in the observed period are near identical for the PDO and SPDO, which also exhibit strong hemispheric symmetry in their spatial patterns, despite their data regions having no geographical overlap. This is suggestive of a common element for these major shifts. Acknowledging the known dynamical links between PDV and ENSO, I find ample distinction between PDV and Niño 3.4 (both patterns and timeseries) to conclude that a smoothed Niño 3.4 index is not a sufficient substitute for the indices of PDV. 
I develop a tool to provide uncertainty quantification of the recent state of PDV, using the TPI (Henley et al. 2015) as an example. I use the tool to provide reliable estimates of IPO state up to 2 years prior to the present, finding that there is an $80-90 \%$ probability that the IPO remained in its negative state until 2014-2015.

I then turn to the pre-instrumental period and review annual resolution palaeoclimate reconstructions of PDV over the last 1000 years, documenting their source data, reconstruction methods and key findings. I then compare the reconstructions in the time and frequency domains, finding that the reconstructions depict a large range of temporal and spectral features, and have generally poor agreement. This reduces the evidence for either: the quality of regionalised palaeoclimate reconstructions as recorders of large-scale modes, their consistency across archive types and methods, stationarity in regional teleconnections to PDV and / or the existence of spatially and temporally coherent PDV in the past millennium. Additional future efforts in data collection, including the development of new proxy data methods, and reconstruction, are critical to resolving these issues. This is particularly true in in the Southern Hemisphere, where palaeoclimate data is much sparser than in the Northern Hemisphere.

I then draw the reader's attention to a Pacific-wide tropical-extratropical mechanism that suggests that the cool and warm phases of PDV are not driven by tropical or extratropical variability alone, but are instead the result of continuous tropical-extratropical interactions on decadal timescales. It is conceivable that the similarities between northern and southern hemisphere PDV patterns arise from basin-wide quasi-symmetric interactions between the tropics and extratropics, in which case the tropics act as a strong synchronising mechanism for both hemispheres. I therefore reason that a range of mechanistic PDV arrangements remain plausible.

There continue to be substantial challenges to research in this field. A significant challenge with the study of PDV is that a high level of expertise is required in multiple fields such as palaeoclimatology, oceanography and atmospheric science. Most palaeoclimate scientists are experts in one proxy and its meticulous collection, but have less expertise on large scale climate dynamics. Most dynamical experts and climate modellers are focussed on shorter timescales and don't have a comprehensive understanding of the utility, purpose, uncertainty and signal in palaeoclimate proxy records. Such are the challenges of many open questions in science and society - multidisciplinary coordination and expertise is a critical feature for future success.

Another significant challenge to the comprehensive picture of PDV is the relatively short and hemispherically asymmetric coverage of observations. In particular, our observations of the intermediate depth ocean are very sparse and short prior to the availability of sub-700m depth ARGO ocean floats in 2005 (Henley et al. 2017). Progress on the synthesis of depth profile data into gridded subsurface datasets (Good et al. 2013; Schmidtko et al. 2013) will 
continue to inform our understanding of PDV. The consistency, quality, continuation and expansion of the observational networks that underpin these analyses is of high importance.

There remain extensive opportunities for improvements in, and renewed efforts in, model development targeting PDV and decadal variability more generally. I would recommend moving beyond EOF patterns, semantics and isolated mechanisms and towards a coherent, focussed and more systematic assessment of the mechanisms of PDV using multiple approaches. Significant opportunities exist in the identification of trigger mechanisms for PDV shifts (Meehl \& Teng 2014; Meehl et al. 2015), and more comprehensive modelling studies that consider interactions between the tropics and extratropics, rather than searching for a single driving mechanism acting in isolation.

Although the slowdown in global warming was widely reported, too little attention has been given to the alternating attenuation and amplification effects of decadal modes on global surface temperatures. Natural variability has cushioned the rise in global temperature since around 2000, and an acceleration in the rate of global warming is likely in the coming decades. Although the slowdown in GMST did not surprise most scientists, it had a detrimental impact on the public perception of our ability to project global temperature. It gave fodder to science contrarians and conspiracy theorists, and temporarily dented the wider public credibility of science. Recall also that the slowdown was at least partly due to PDV. Hence, one might infer that a better understanding of PDV has an impact on the public credibility of science as a whole.

Given the global implications of decadal to multidecadal climate variability on human and natural systems, for scientists and managers in climate, water resources, earth science, palaeoclimatology, geography, biology, ecology, oceanography and atmospheric science, it is critical that we bolster efforts to understand decadal climate variability. Pacific decadal variability should therefore should be a critical focus area for several disciplines in the climate sciences. In the coming years and decades, we need a bolstering of the efforts to understand, model and measure the past and future trajectory of Pacific decadal climate variability and its impacts on the future climate. 
674 Table 1. Summary of definitions, datasets and analysis methods of IPO and PDO indices, 675 following Henley et al. (2015)

\begin{tabular}{|c|c|c|c|c|c|c|c|c|}
\hline $\begin{array}{l}\text { Authors } \\
\text { and year }\end{array}$ & $\begin{array}{c}\text { Primary Base } \\
\text { Dataset(s) }\end{array}$ & $\begin{array}{c}\text { Spatial } \\
\text { resolution }\end{array}$ & Domain & $\begin{array}{c}\text { Time } \\
\text { resolution }\end{array}$ & $\begin{array}{l}\text { Period of } \\
\text { Analysis }\end{array}$ & Filtering & Method & Index Definition \\
\hline $\begin{array}{l}\text { Mantua } \\
\text { et al. } \\
\text { (1997) }\end{array}$ & HSSTD / OISST & $5^{\circ} \times 5^{\circ} / 1^{\circ} \times 1^{\circ}$ & $\begin{array}{l}\text { Poleward } \\
\text { of } 20^{\circ} \mathrm{N}\end{array}$ & Monthly & $\begin{array}{l}1900- \\
1993\end{array}$ & None & $\mathrm{PCA}^{\#}$ & $\begin{array}{l}\text { PC1 of SST over } \\
\text { Pacific domain }\end{array}$ \\
\hline $\begin{array}{l}\text { Zhang et } \\
\text { al. } \\
(1997)\end{array}$ & COADS / HSSTD & $\begin{array}{l}2^{\circ} \times 2^{\circ}, \\
\text { aggregated to } 4^{\circ} \\
\times 6^{\circ}\end{array}$ & $\begin{array}{l}\text { Poleward } \\
\text { of } 20^{\circ} \mathrm{N}\end{array}$ & Monthly & $\begin{array}{l}1900- \\
1993\end{array}$ & $\begin{array}{l}\text { 6-yr low } \\
\text { pass }\end{array}$ & PCA & $\begin{array}{l}\text { PC1 of low pass } \\
\text { filtered SST over } \\
\text { Pacific domain }\end{array}$ \\
\hline $\begin{array}{l}\text { Folland } \\
\text { et al. } \\
\text { (1999) }\end{array}$ & $\begin{array}{l}\text { MOHSST6C/NMAT } \\
\text { (Parker et al. 1995) }\end{array}$ & $\begin{array}{l}\text { Equal areas, } 10^{\circ} \\
\times 12^{\circ} \text { at equator }\end{array}$ & Global & Seasonal & $\begin{array}{l}1861- \\
1996\end{array}$ & $\begin{array}{l}\text { 13-yr low } \\
\text { pass }\end{array}$ & PCA & $\begin{array}{l}\text { Projection of } \\
\text { unfiltered } \\
\text { MOHSST6C onto } \\
\text { low-pass filtered } \\
\text { EOF2 for 1861- } \\
\text { 1996, then } \\
\text { filtered to obtain } \\
\text { low frequency } \\
\text { version }\end{array}$ \\
\hline $\begin{array}{l}\text { Power et } \\
\text { al. } \\
(1999)\end{array}$ & MOHSST6 / NMAT & Various & $\begin{array}{l}\text { Global } \\
\text { and } \\
\text { North } \\
\text { Pacific }\end{array}$ & $\begin{array}{l}\text { Seasonal } \\
\text { and } \\
\text { Annual }\end{array}$ & $\begin{array}{l}1856- \\
1998\end{array}$ & $\begin{array}{l}\text { 13-yr low } \\
\text { pass }\end{array}$ & PCA & PC1 \\
\hline $\begin{array}{l}\text { Cai \& } \\
\text { Whetton } \\
\text { (2001) }\end{array}$ & GISST3 & $5^{\circ} \times 5^{\circ}$ & Global & Annual & $\begin{array}{l}1880- \\
1997\end{array}$ & $\begin{array}{l}11-y r \text { low } \\
\text { pass } \\
\text { Butterworth }\end{array}$ & PCA & PC2 \\
\hline $\begin{array}{l}\text { Folland } \\
\text { et al. } \\
\text { (2002) }\end{array}$ & $\begin{array}{l}\text { as for Folland et al. } \\
\text { (1999) }\end{array}$ & $\begin{array}{l}\text { As for Folland et } \\
\text { al } 1999\end{array}$ & Global & Annual & $\begin{array}{l}1911- \\
1995\end{array}$ & $\begin{array}{l}\text { 13-yr low } \\
\text { pass }\end{array}$ & PCA & $\begin{array}{l}\text { as for Folland et } \\
\text { al. (1999) }\end{array}$ \\
\hline $\begin{array}{l}\text { Parker et } \\
\text { al. } \\
(2007)\end{array}$ & $\begin{array}{l}\text { HadCRUT3 } \\
\text { Rayner et al. } \\
\text { (2006) }\end{array}$ & $\begin{array}{l}\text { Equal areas, } 10^{\circ} \\
\times 12^{\circ} \text { at equator }\end{array}$ & Global & Seasonal & $\begin{array}{l}1850- \\
2006\end{array}$ & $\begin{array}{l}11-y r \text { low } \\
\text { pass } \\
\text { Chebyshev }\end{array}$ & PCA & $\begin{array}{l}\text { Projection of } \\
\text { unfiltered } \\
\text { HadSST2 onto } \\
\text { low-pass filtered } \\
\text { EOF2 for 1891- } \\
2001 \text {, then } \\
\text { filtered to obtain } \\
\text { low frequency } \\
\text { version }\end{array}$ \\
\hline $\begin{array}{l}\text { Henley } \\
\text { et al. } \\
\text { (2015) }\end{array}$ & $\begin{array}{l}\text { HadISST1, } \\
\text { HadISST2.1, } \\
\text { ERSSTV3b, } \\
\text { HadSST3.1 }\end{array}$ & $1^{\circ} \times 1^{\circ}$ & Global & Monthly & $\begin{array}{l}1870- \\
2007\end{array}$ & $\begin{array}{l}\text { 13-yr low } \\
\text { pass } \\
\text { Chebyshev }\end{array}$ & $\begin{array}{l}\text { Box- } \\
\text { based } \\
\text { linear } \\
\text { sum }\end{array}$ & $\begin{array}{l}\text { Linear sum of de- } \\
\text { seasonalised } \\
\text { mean SST data } \\
\text { in three regions: } \\
\\
\text { TPI }=\mathrm{R}_{2^{-}} \\
\left(\mathrm{R}_{1}+\mathrm{R}_{3}\right) / 2 \\
\mathrm{R}_{1}=\left[25^{\circ} \mathrm{N}-45^{\circ} \mathrm{N},\right. \\
\left.140^{\circ} \mathrm{E}-145^{\circ} \mathrm{W}\right] \\
\mathrm{R}_{2}=\left[10^{\circ} \mathrm{S}-10^{\circ} \mathrm{N},\right. \\
\left.170^{\circ} \mathrm{E}-90^{\circ} \mathrm{W}\right] \\
\mathrm{R}_{3}=\left[50^{\circ} \mathrm{S}-15^{\circ} \mathrm{S}\right. \\
\left.150^{\circ} \mathrm{E}-160^{\circ} \mathrm{W}\right]\end{array}$ \\
\hline
\end{tabular}


679 Table 2. Correlations between IPO and PDO reconstructions. Spearman correlations 680 computed for full overlapping period between paired IPO and PDO reconstructions; p-value 681 shown in parentheses is adjusted for serial autocorrelation; bold entries indicate statistical 682 significance at the $5 \%$ level

\begin{tabular}{|c|c|c|c|c|c|c|c|c|c|c|c|c|}
\hline 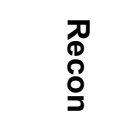 & 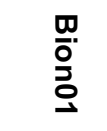 & 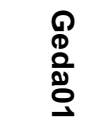 & 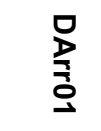 & 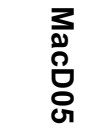 & 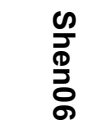 & 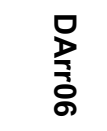 & $\begin{array}{l}\frac{\nwarrow}{0} \\
\frac{0}{\circ}\end{array}$ & 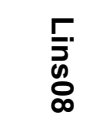 & \begin{tabular}{l}
3 \\
\multirow{3}{3}{} \\
$\overline{5}$ \\
8 \\
0
\end{tabular} & $\begin{array}{l}3 \\
\stackrel{a}{\Omega} \\
\stackrel{a}{0}\end{array}$ & $\begin{array}{l}\underset{\Phi}{\Phi} \\
\stackrel{\text { I }}{\Xi}\end{array}$ & 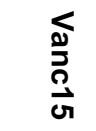 \\
\hline Bion01 & & $\begin{array}{c}0.17 \\
(0.00)\end{array}$ & $\begin{array}{c}0.18 \\
(0.00)\end{array}$ & $\begin{array}{c}0.54 \\
(0.00)\end{array}$ & $\begin{array}{c}0.16 \\
(0.00)\end{array}$ & $\begin{array}{c}0.11 \\
(0.06)\end{array}$ & $\begin{array}{c}0.29 \\
(0.00)\end{array}$ & $\begin{array}{c}0.04 \\
(0.52)\end{array}$ & $\begin{array}{c}-0.37 \\
(0.00)\end{array}$ & $\begin{array}{c}0.33 \\
(0.00)\end{array}$ & $\begin{array}{l}-0.01 \\
(0.85)\end{array}$ & $\begin{array}{c}0.20 \\
(0.00)\end{array}$ \\
\hline Geda01 & $\begin{array}{c}0.17 \\
(0.00)\end{array}$ & & $\begin{array}{c}0.32 \\
(0.00)\end{array}$ & $\begin{array}{c}0.15 \\
(0.00)\end{array}$ & $\begin{array}{c}0.08 \\
(0.10)\end{array}$ & $\begin{array}{c}0.01 \\
(0.82)\end{array}$ & $\begin{array}{c}0.20 \\
(0.00)\end{array}$ & $\begin{array}{c}0.01 \\
(0.80)\end{array}$ & $\begin{array}{l}-0.04 \\
(0.40)\end{array}$ & $\begin{array}{c}0.31 \\
(0.00)\end{array}$ & $\begin{array}{l}-0.02 \\
(0.63)\end{array}$ & $\begin{array}{c}0.07 \\
(0.15)\end{array}$ \\
\hline DArr01 & $\begin{array}{c}0.18 \\
(0.00)\end{array}$ & $\begin{array}{c}0.32 \\
(0.00)\end{array}$ & & $\begin{array}{c}0.15 \\
(0.01)\end{array}$ & $\begin{array}{c}0.10 \\
(0.10)\end{array}$ & $\begin{array}{c}0.04 \\
(0.51)\end{array}$ & $\begin{array}{c}0.36 \\
(0.00)\end{array}$ & $\begin{array}{c}0.06 \\
(0.36)\end{array}$ & $\begin{array}{l}-0.13 \\
(0.03)\end{array}$ & $\begin{array}{c}0.34 \\
(0.00)\end{array}$ & $\begin{array}{c}0.25 \\
(0.00)\end{array}$ & $\begin{array}{c}0.24 \\
(0.00)\end{array}$ \\
\hline MacD05 & $\begin{array}{c}0.54 \\
(0.00)\end{array}$ & $\begin{array}{c}0.15 \\
(0.00)\end{array}$ & $\begin{array}{c}0.15 \\
(0.01)\end{array}$ & & $\begin{array}{c}0.05 \\
(0.23)\end{array}$ & $\begin{array}{c}-0.02 \\
(0.68)\end{array}$ & $\begin{array}{c}0.31 \\
(0.00)\end{array}$ & $\begin{array}{c}0.01 \\
(0.86)\end{array}$ & $\begin{array}{l}-0.37 \\
(0.00)\end{array}$ & $\begin{array}{c}0.19 \\
(0.00)\end{array}$ & $\begin{array}{c}0.01 \\
(0.84)\end{array}$ & $\begin{array}{c}0.03 \\
(0.40)\end{array}$ \\
\hline Shen06 & $\begin{array}{c}0.16 \\
(0.00)\end{array}$ & $\begin{array}{c}0.08 \\
(0.10)\end{array}$ & $\begin{array}{c}0.10 \\
(0.10)\end{array}$ & $\begin{array}{c}0.05 \\
(0.23)\end{array}$ & & $\begin{array}{c}0.03 \\
(0.49)\end{array}$ & $\begin{array}{c}0.18 \\
(0.00)\end{array}$ & $\begin{array}{c}0.13 \\
(0.01)\end{array}$ & $\begin{array}{c}0.03 \\
(0.50)\end{array}$ & $\begin{array}{c}0.05 \\
(0.35)\end{array}$ & $\begin{array}{c}0.22 \\
(0.00)\end{array}$ & $\begin{array}{c}0.07 \\
(0.11)\end{array}$ \\
\hline DArr06 & $\begin{array}{c}0.11 \\
(0.06)\end{array}$ & $\begin{array}{c}0.01 \\
(0.82)\end{array}$ & $\begin{array}{c}0.04 \\
(0.51)\end{array}$ & $\begin{array}{l}-0.02 \\
(0.68)\end{array}$ & $\begin{array}{c}0.03 \\
(0.49)\end{array}$ & & $\begin{array}{c}0.02 \\
(0.78)\end{array}$ & $\begin{array}{c}0.20 \\
(0.00)\end{array}$ & $\begin{array}{l}-0.06 \\
(0.24)\end{array}$ & $\begin{array}{c}0.00 \\
(0.97)\end{array}$ & $\begin{array}{c}0.41 \\
(0.00)\end{array}$ & $\begin{array}{c}0.05 \\
(0.31)\end{array}$ \\
\hline Verd06 & $\begin{array}{c}0.29 \\
(0.00)\end{array}$ & $\begin{array}{c}0.20 \\
(0.00)\end{array}$ & $\begin{array}{c}0.36 \\
(0.00)\end{array}$ & $\begin{array}{c}0.31 \\
(0.00)\end{array}$ & $\begin{array}{c}0.18 \\
(0.00)\end{array}$ & $\begin{array}{c}0.02 \\
(0.78)\end{array}$ & & $\begin{array}{l}-0.05 \\
(0.41)\end{array}$ & $\begin{array}{l}-0.13 \\
(0.05)\end{array}$ & $\begin{array}{c}0.39 \\
(0.00)\end{array}$ & $\begin{array}{c}0.21 \\
(0.00)\end{array}$ & $\begin{array}{c}0.41 \\
(0.00)\end{array}$ \\
\hline Lins08 & $\begin{array}{c}0.04 \\
(0.52)\end{array}$ & $\begin{array}{c}0.01 \\
(0.80)\end{array}$ & $\begin{array}{c}0.06 \\
(0.36)\end{array}$ & $\begin{array}{c}0.01 \\
(0.86)\end{array}$ & $\begin{array}{c}0.13 \\
(0.01)\end{array}$ & $\begin{array}{c}0.20 \\
(0.00)\end{array}$ & $\begin{array}{l}-0.05 \\
(0.41)\end{array}$ & & $\begin{array}{l}-0.08 \\
(0.16)\end{array}$ & $\begin{array}{c}0.20 \\
(0.00)\end{array}$ & $\begin{array}{c}0.34 \\
(0.00)\end{array}$ & $\begin{array}{c}0.10 \\
(0.08)\end{array}$ \\
\hline Mann09 & $\begin{array}{c}-0.37 \\
(0.00)\end{array}$ & $\begin{array}{l}-0.04 \\
(0.40)\end{array}$ & $\begin{array}{c}-0.13 \\
(0.03)\end{array}$ & $\begin{array}{c}-0.37 \\
(0.00)\end{array}$ & $\begin{array}{c}0.03 \\
(0.50)\end{array}$ & $\begin{array}{c}-0.06 \\
(0.24)\end{array}$ & $\begin{array}{c}-0.13 \\
(0.05)\end{array}$ & $\begin{array}{c}-0.08 \\
(0.16)\end{array}$ & & $\begin{array}{l}-0.42 \\
(0.01)\end{array}$ & $\begin{array}{c}-0.04 \\
(0.48)\end{array}$ & $\begin{array}{c}0.17 \\
(0.01)\end{array}$ \\
\hline McGr10 & $\begin{array}{c}0.33 \\
(0.00)\end{array}$ & $\begin{array}{c}0.31 \\
(0.00)\end{array}$ & $\begin{array}{c}0.34 \\
(0.00)\end{array}$ & $\begin{array}{c}0.19 \\
(0.00)\end{array}$ & $\begin{array}{c}0.05 \\
(0.35)\end{array}$ & $\begin{array}{c}0.00 \\
(0.97)\end{array}$ & $\begin{array}{c}0.39 \\
(0.00)\end{array}$ & $\begin{array}{c}0.20 \\
(0.00)\end{array}$ & $\begin{array}{r}-0.42 \\
(0.01)\end{array}$ & & $\begin{array}{c}0.08 \\
(0.25)\end{array}$ & $\begin{array}{c}0.33 \\
(0.01)\end{array}$ \\
\hline Henl11 & $\begin{array}{l}-0.01 \\
(0.85)\end{array}$ & $\begin{array}{l}-0.02 \\
(0.63)\end{array}$ & $\begin{array}{c}0.25 \\
(0.00)\end{array}$ & $\begin{array}{c}0.01 \\
(0.84)\end{array}$ & $\begin{array}{c}0.22 \\
(0.00)\end{array}$ & $\begin{array}{c}0.41 \\
(0.00)\end{array}$ & $\begin{array}{c}0.21 \\
(0.00)\end{array}$ & $\begin{array}{c}0.34 \\
(0.00)\end{array}$ & $\begin{array}{l}-0.04 \\
(0.48)\end{array}$ & $\begin{array}{c}0.08 \\
(0.25)\end{array}$ & & $\begin{array}{c}0.36 \\
(0.00)\end{array}$ \\
\hline Vanc15 & $\begin{array}{c}0.20 \\
(0.00)\end{array}$ & $\begin{array}{c}0.07 \\
(0.15)\end{array}$ & $\begin{array}{c}0.24 \\
(0.00)\end{array}$ & $\begin{array}{c}0.03 \\
(0.40)\end{array}$ & $\begin{array}{c}0.07 \\
(0.11)\end{array}$ & $\begin{array}{c}0.05 \\
(0.31)\end{array}$ & $\begin{array}{c}0.41 \\
(0.00)\end{array}$ & $\begin{array}{c}0.10 \\
(0.08)\end{array}$ & $\begin{array}{c}0.17 \\
(0.01)\end{array}$ & $\begin{array}{c}0.33 \\
(0.01)\end{array}$ & $\begin{array}{c}0.36 \\
(0.00)\end{array}$ & \\
\hline
\end{tabular}


a

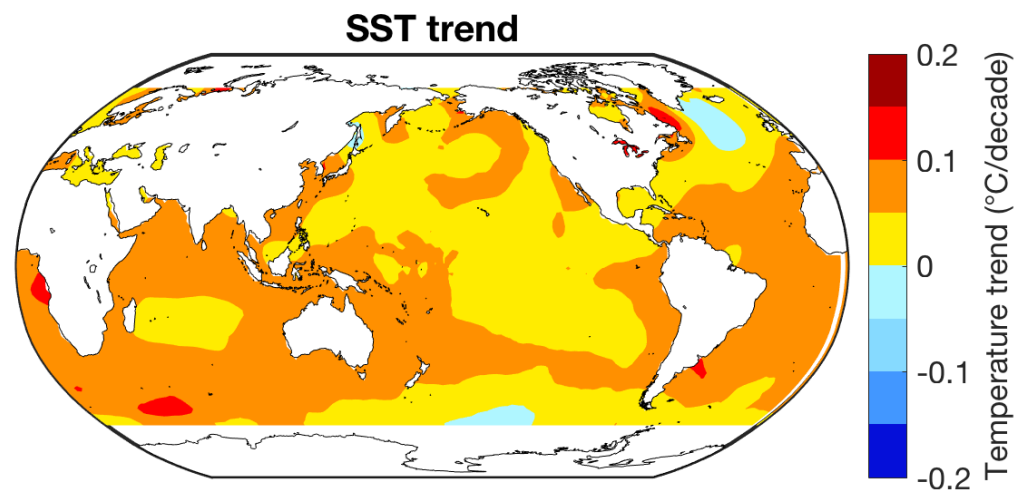

b

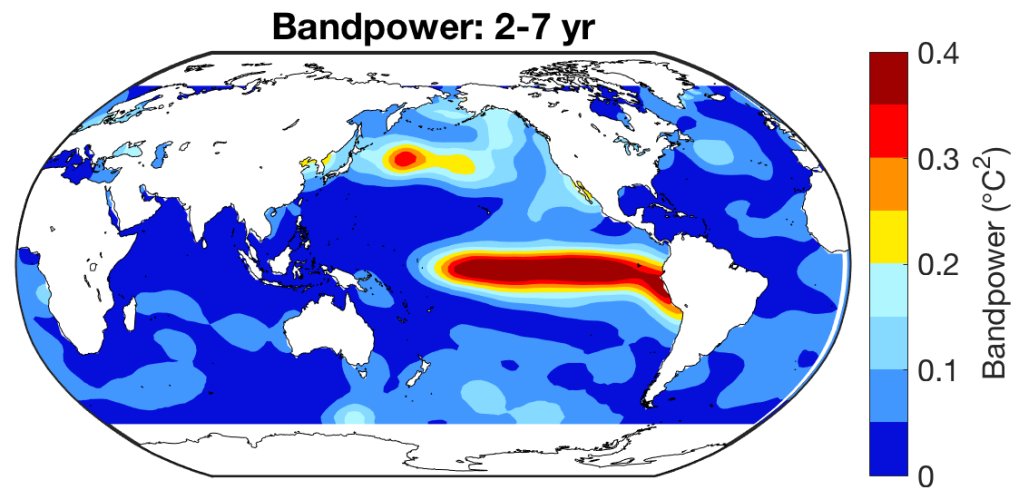

c

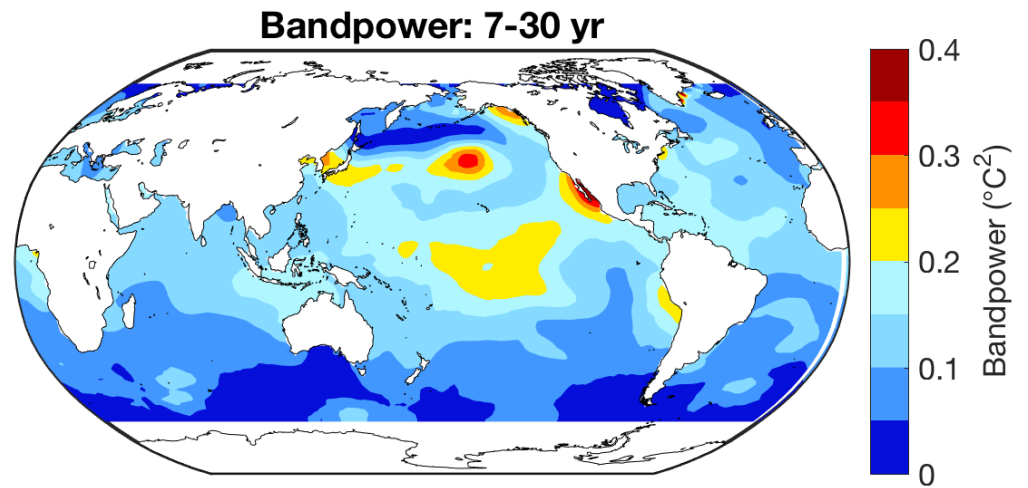

d

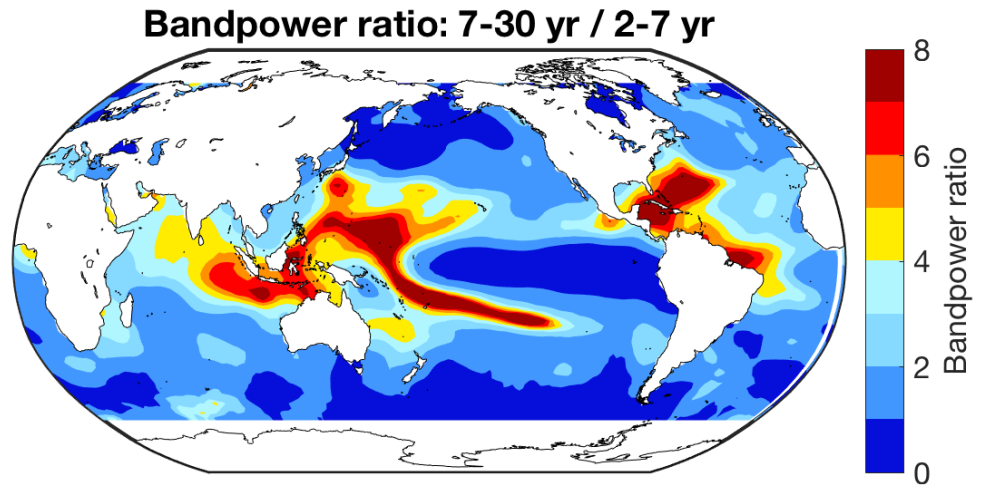

Figure 1. Trend and persistence in global sea surface temperature for 1900-2016. a) Trend in global SST (linear regression coefficient), b) average bandpower in the 2-7 year and c) 7-30 year frequency bands and d) ratio of bandpower between the two bands. 

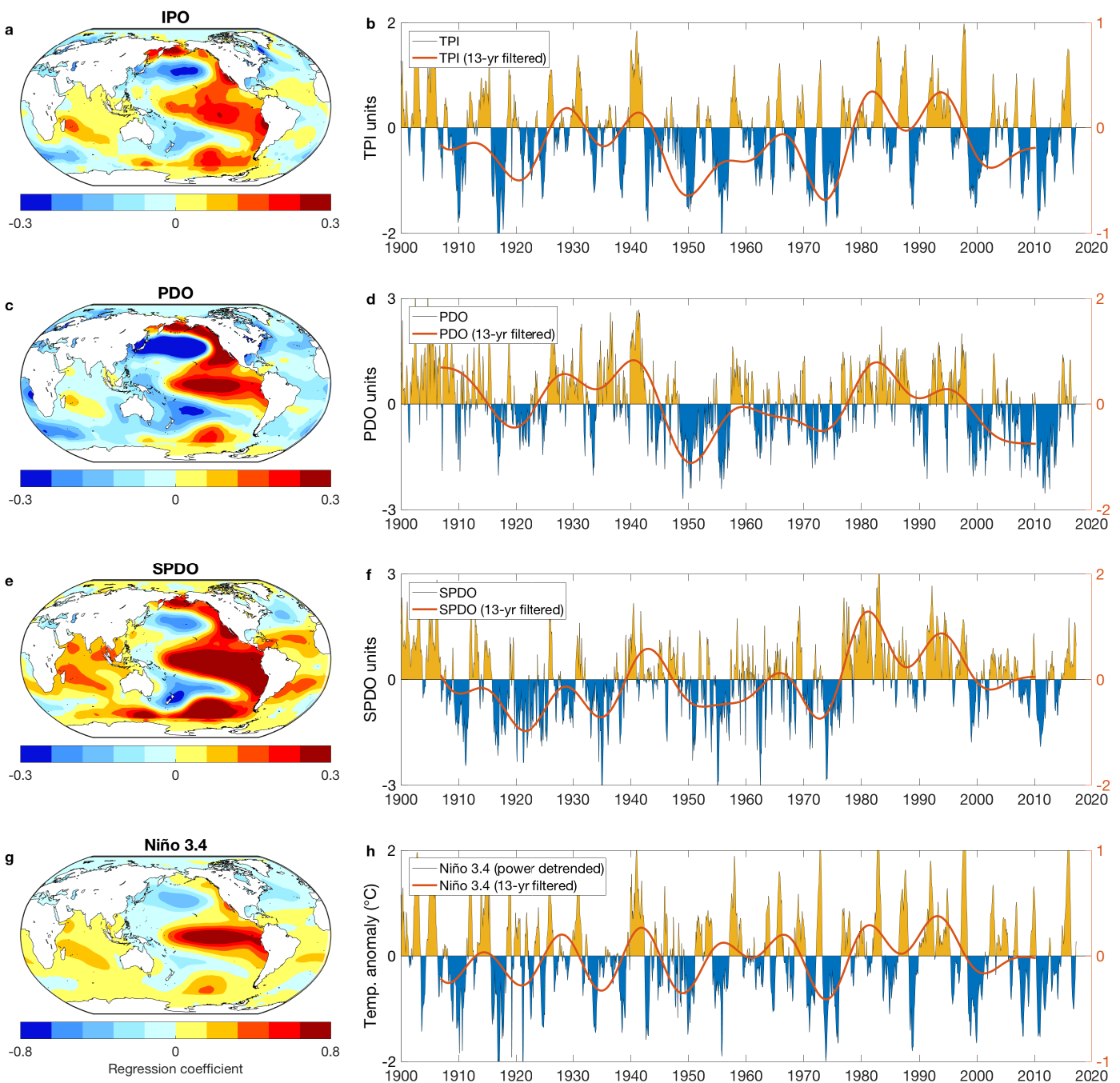

Figure 2. Pacific SST regression patterns and timeseries 1900-2016. a) IPO (TPI) pattern and b) timeseries, c) PDO pattern and d) timeseries, e) SPDO pattern and f) timeseries, g) Niño 3.4 pattern and h) timeseries; Patterns are the regression of global SST onto the unfiltered indices; unfiltered timeseries are shown as shaded anomalies; smoothed series use a 13-year Chebyshev low-pass filter. 


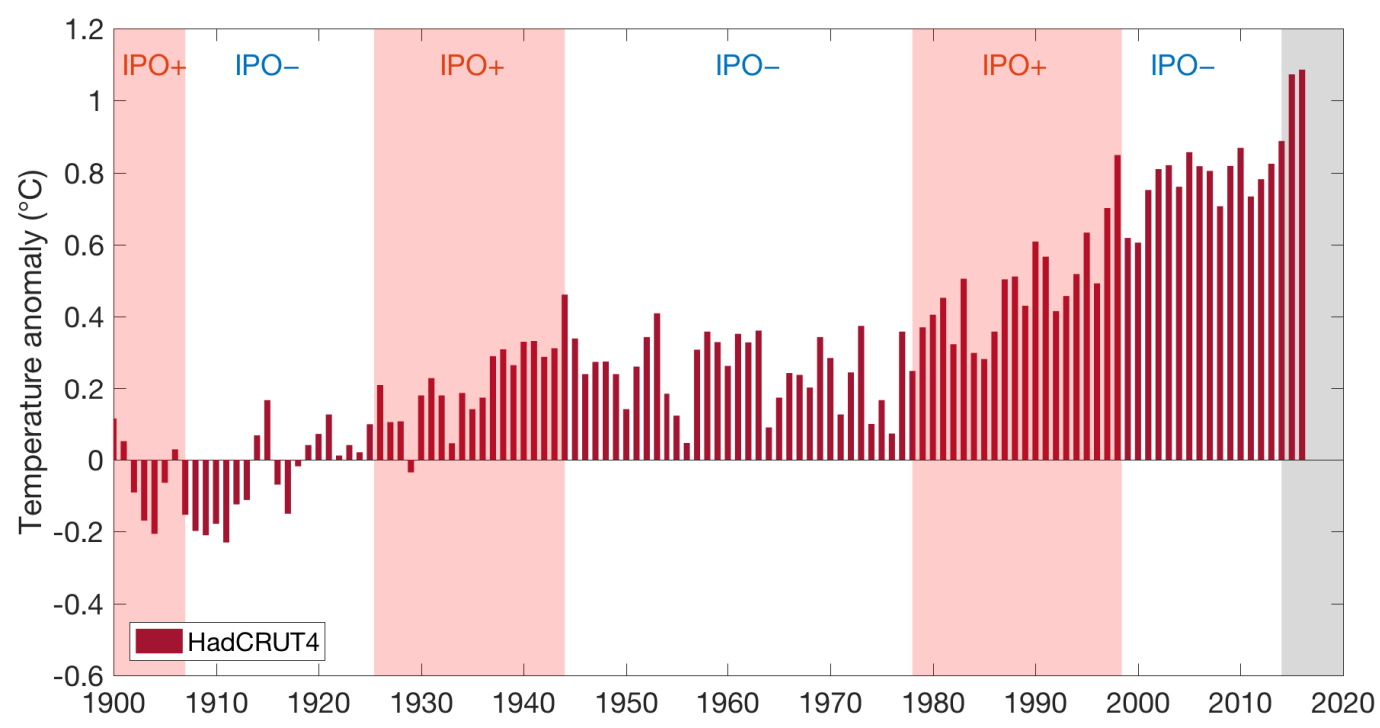

696 Figure 3. Global mean surface temperature anomaly and the IPO (1900-2016). Observed annual global mean surface temperature anomaly (red bars, HadCRUT4, 1850-1900 baseline);

698 Major decadal IPO negative and positive periods are shown as alternating pink (IPO positive) 699 and white (IPO negative) bands, adapted from England et al. (2014) and Henley \& King $700 \quad$ (2017). 


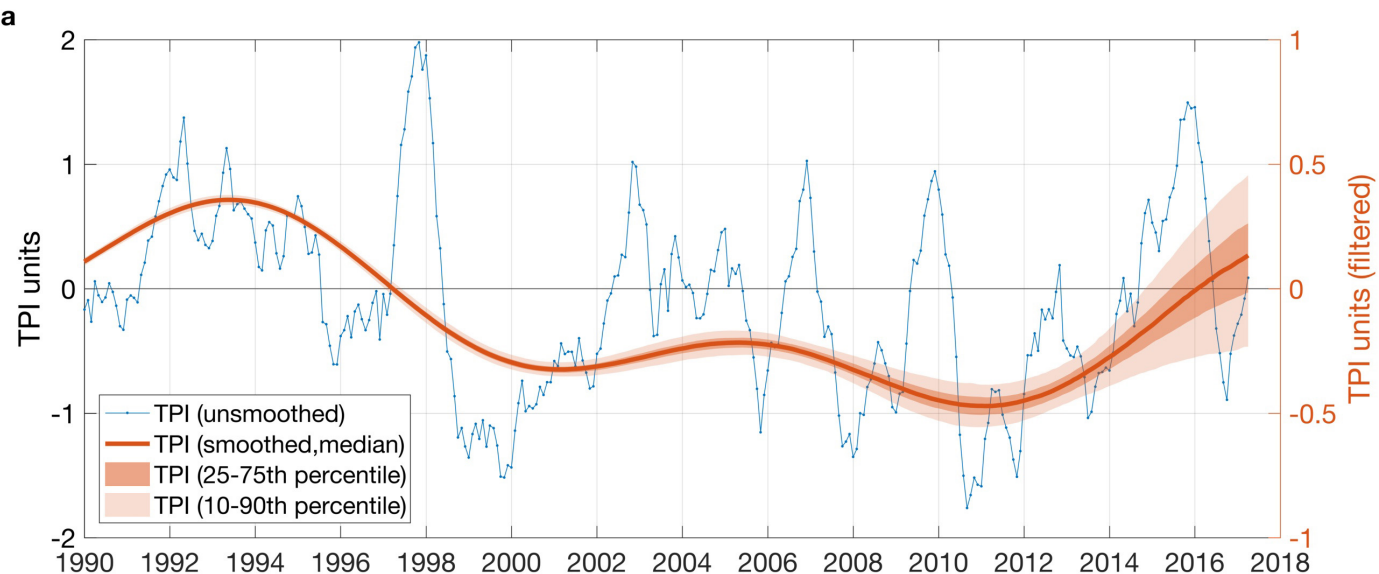

b
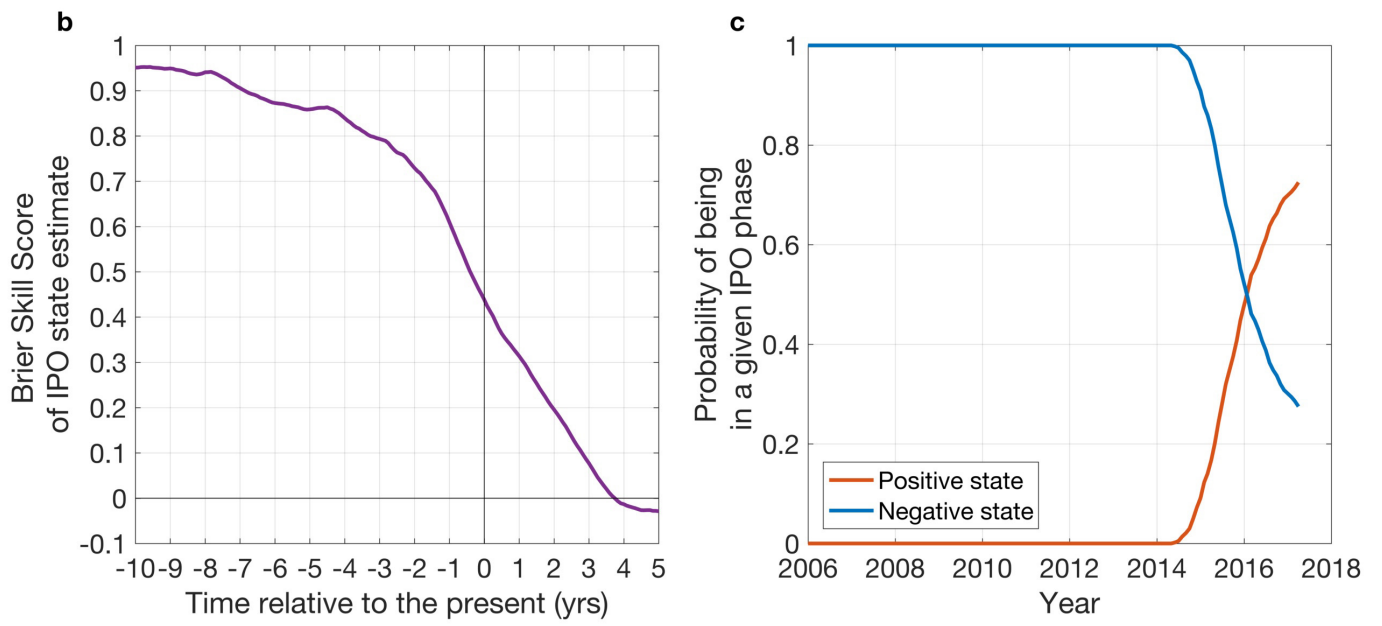

Figure 4. A scheme to quantify the IPO state in the recent past. a) Unfiltered TPI timeseries (blue, 1990-2017) and an ensemble distribution of the low-pass filtered TPI (red, 1990-2017) using observed data for the past values and stochastic simulations for the future. Uncertainty is represented using 1000 replicates of a monthly AR(5) model (order optimised using Schwarz's Bayesian Criterion; Schwarz 1978) conditioned on the most recent data available; a 13-year low-pass Chebyshev filter is applied across the past-future boundary; b) Brier skill score for the IPO state estimation scheme in each year relative to the current year, skill is computed for the period 1900-2000; positive values represent skill in the probability estimate relative to random chance (note the influence of serial dependence; Wilks, 2010); c) Probability of IPO states 2006-2017 using the IPO state estimation scheme conditioned on the most recent TPI data available. 


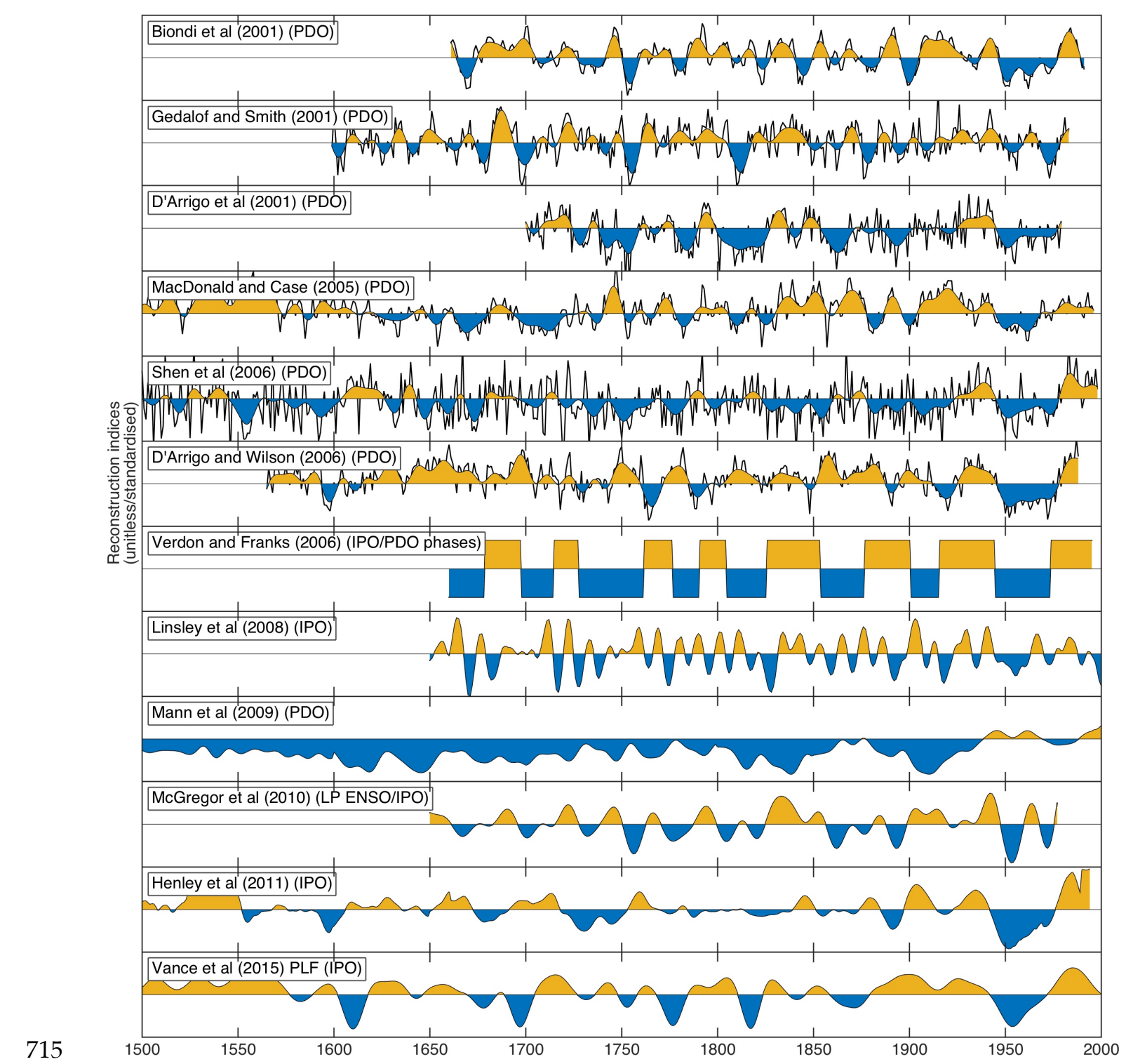

Figure 5. Palaeoclimate reconstructions of the PDO and IPO for 1500-2000. Low frequency reconstructions shown in blue and yellow shaded anomalies (around zero line); unsmoothed series shown in black where available; Reconstructions based on North American tree rings (Biondi et al. 2001; Gedalof \& Smith 2001; D’Arrigo et al. 2001; MacDonald \& Case 2005), Asian tree rings (D’Arrigo \& Wilson 2006), Documentary records (Shen et al. 2006), multiproxy composites of site records or reconstructions (Verdon \& Franks 2006; Mann et al. 2009; McGregor et al. 2010; Henley et al. 2011), South Pacific Coral $\partial^{18} \mathrm{O}$ (Linsley et al. 2008) and the Law Dome ice core from Antarctica (Vance et al. 2015) 

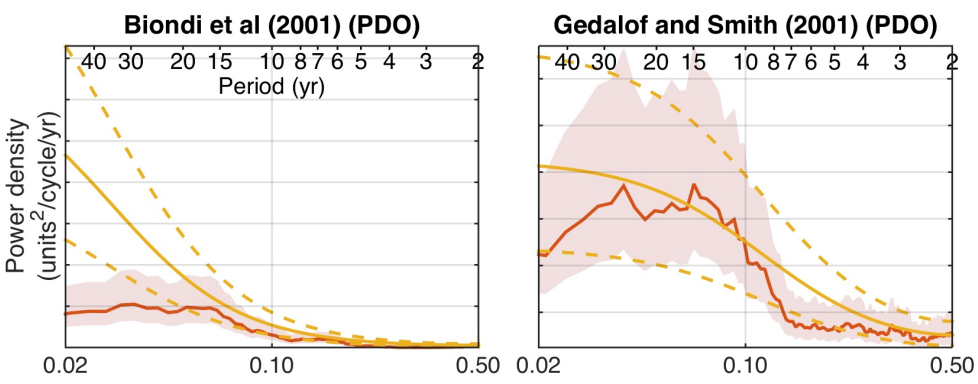

D'Arrigo et al (2001) (PDO)
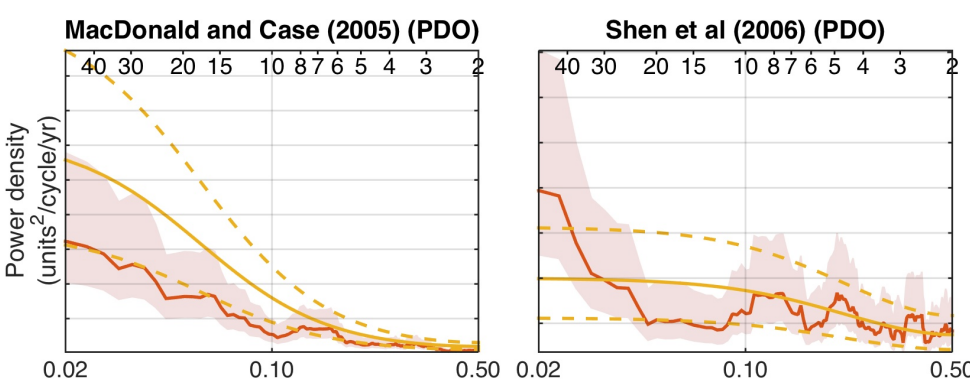

50.02
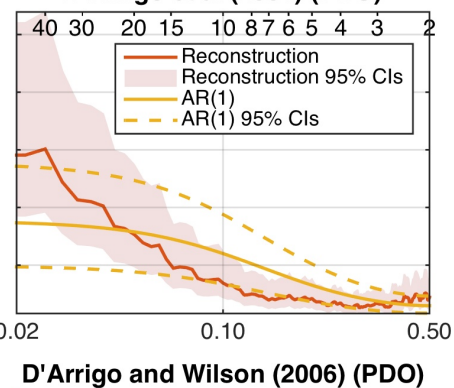

Verdon and Franks (2006) (IPO/PDO phases)
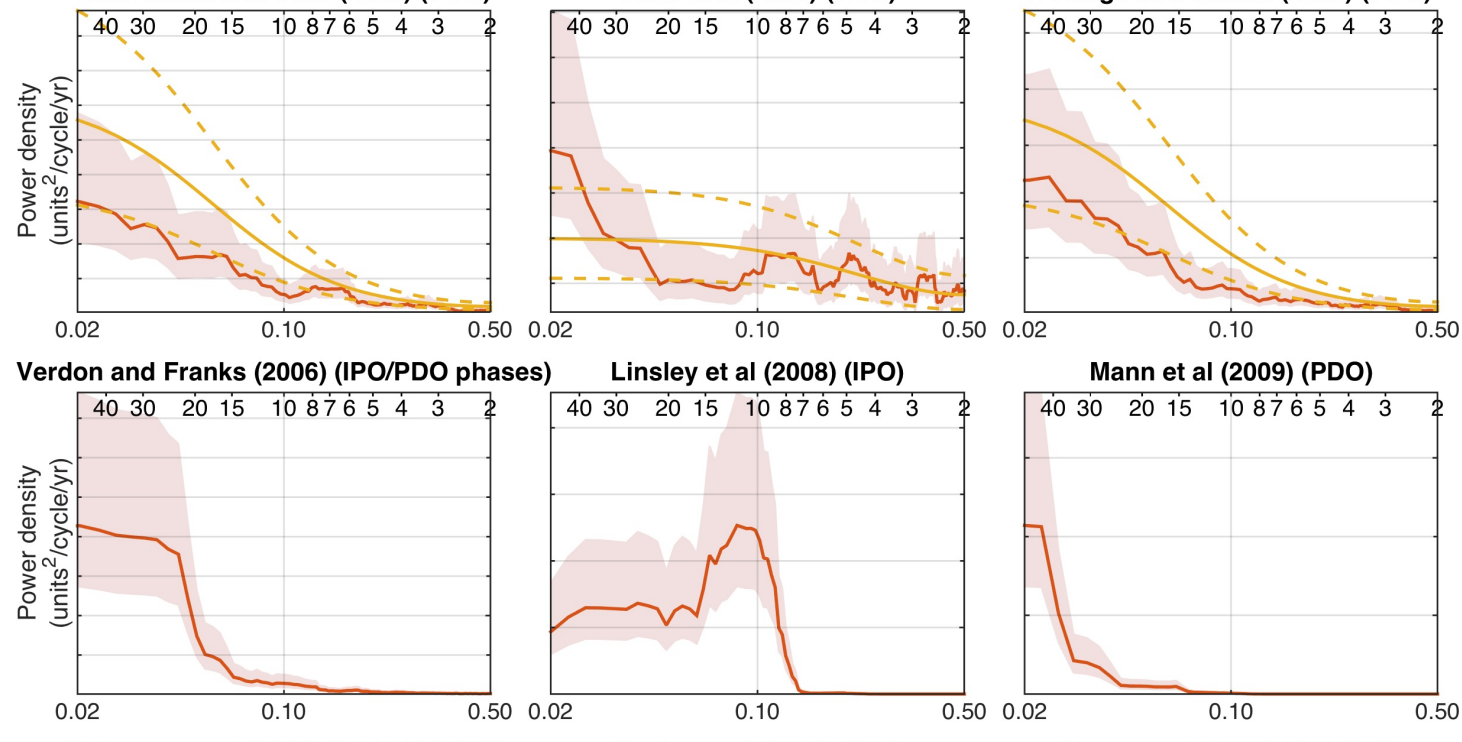

McGregor et al (2010) (LP ENSO/IPO)

Henley et al (2011) (IPO)
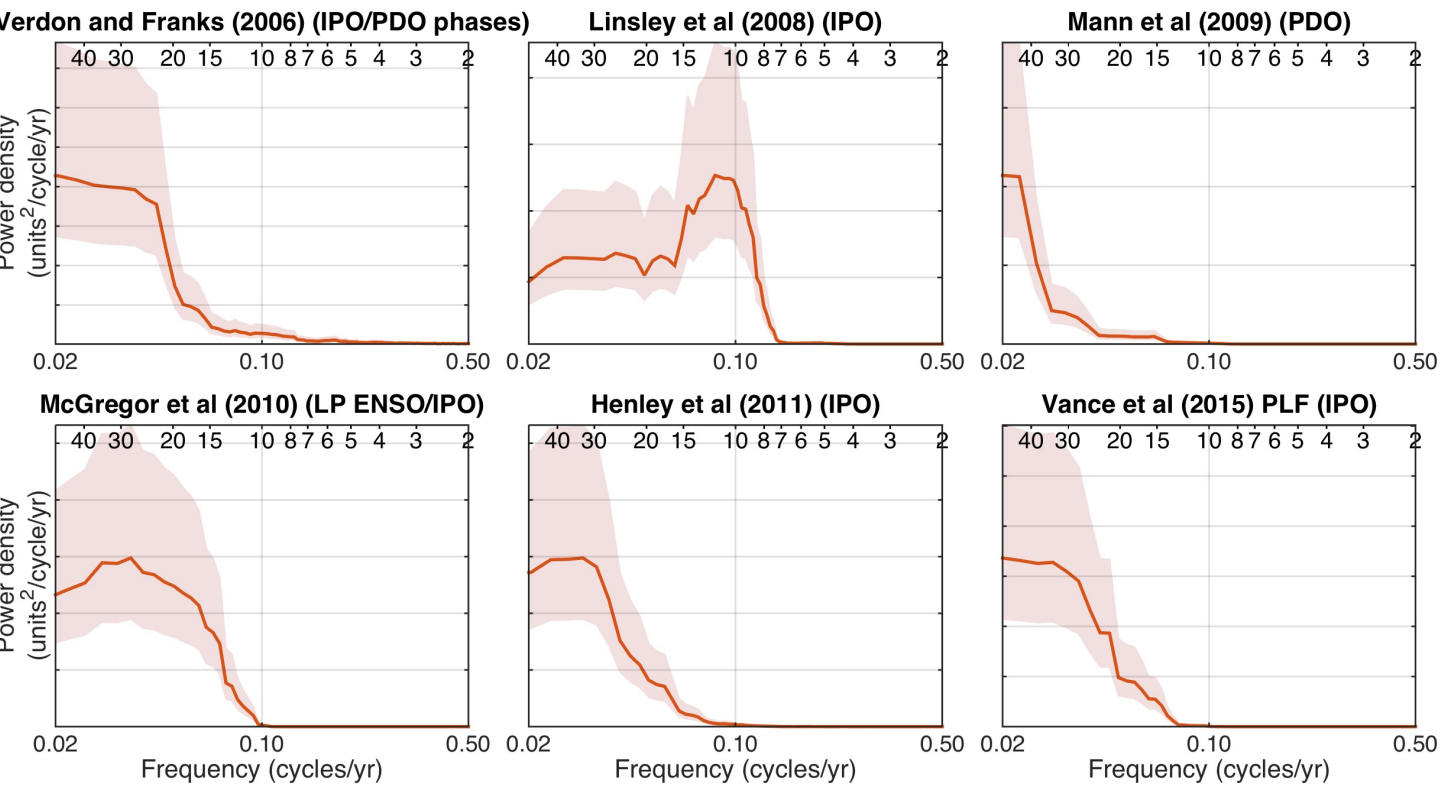

Figure 6. Power spectra of IPO and PDO reconstructions (1700 CE - recent). Multi-taper method (MTM) power spectra and 95\% confidence intervals of IPO and PDO reconstructions (red/pink); AR(1) spectra and 95\% confidence intervals shown for reconstructions where unfiltered indices are available (orange solid and dashed); 


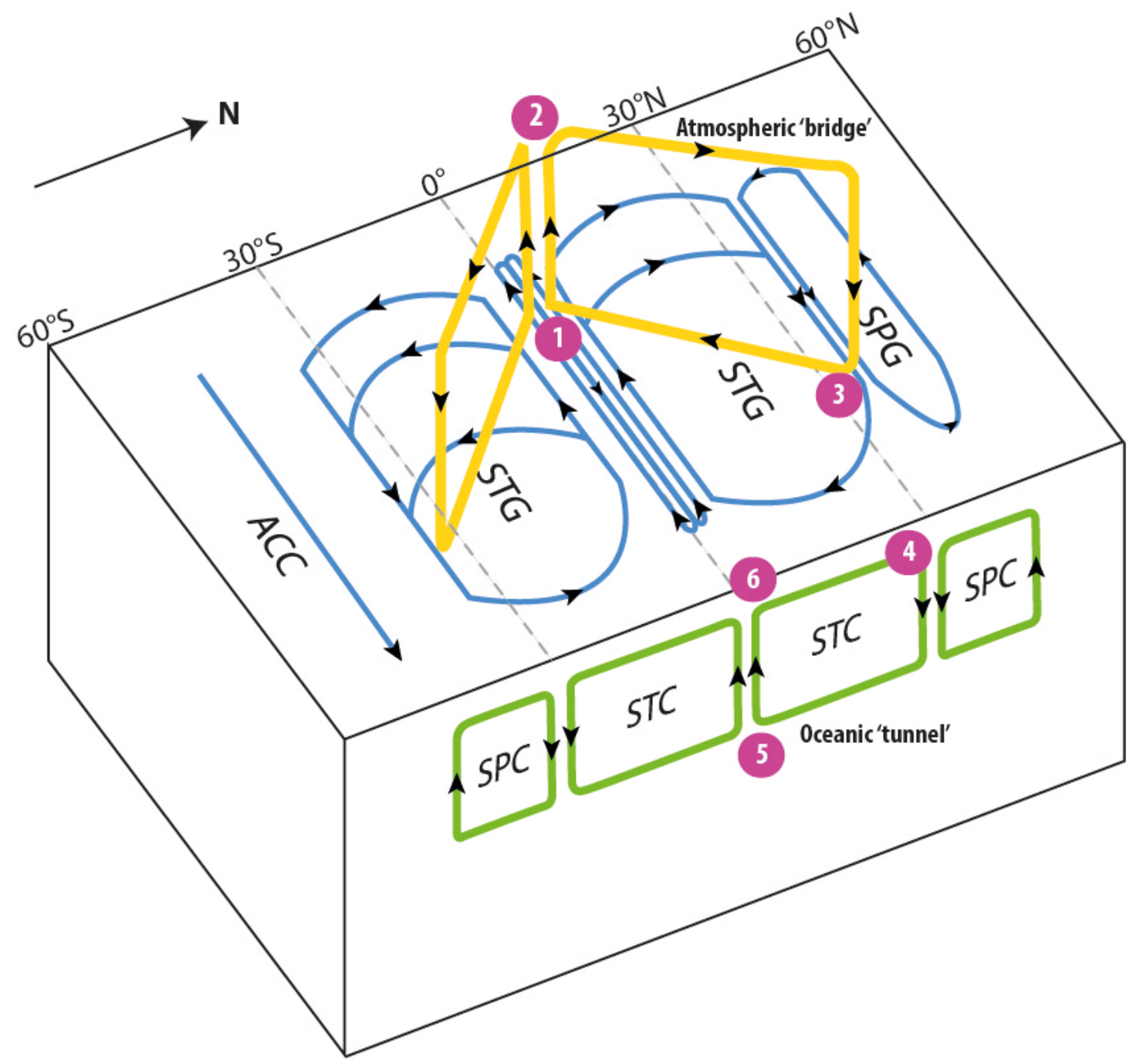

Figure 7. Schematic of a PDV mechanism with tropical-extratropical interactions on decadal timescales. Idealised Hadley cell is shown in yellow, ocean surface layer gyres in blue: Subtropical Gyre (STG), Subpolar Gyre (SPG) and Antartic Circumpolar Current (ACC); Vertical overturning cells in the ocean shown in green: Subtropical Cell (STC), Subpolar Cell (SPC); diagram is an adaptation from Farneti et al. (2014), England et al. (2014) and Lu et al. (1998); 


\section{References}

Allan, R.J., 2000. ENSO and climatic variability in the past 150 years. In H. F. Diaz \& V. Markgraf, eds. El Niño and the Southern Oscillation: Multiscale Variability and Its Impacts on Natural Ecosystems and Society. Cambridge University Press, pp. 3-45.

Ault, T.R. et al., 2016. Relative impacts of mitigation, temperature, and precipitation on 21stcentury megadrought risk in the American Southwest. Science Advances, pp.1-9.

Batehup, R., McGregor, S. \& Gallant, A.J.E., 2015. The influence of non-stationary teleconnections on palaeoclimate reconstructions of ENSO variance using a pseudoproxy framework. Climate of the Past, 11(12), pp.1733-1749.

Biondi, F., Gershunov, A. \& Cayan, D.R., 2001. North Pacific Decadal Climate Variability since 1661. Journal of Climate, 14(1), pp.5-10.

Boer, G.J. et al., 2016. The Decadal Climate Prediction Project (DCPP) contribution to CMIP6. Geoscientific Model Development, 9(10), pp.3751-3777.

Cai, W. \& Whetton, P., 2001. Modes of SST variability and the fluctuation of global mean temperature. Climate dynamics, 17(11), pp.889-901.

Chen, X. \& Wallace, J.M., 2015. ENSO-like variability: 1900-2013. Journal of Climate, 28(24), pp.9623-9641.

Christensen, J.H. et al., 2013. Climate phenomena and their relevance for future regional climate change. In T. F. Stocker et al., eds. Climate Change 2013: The Physical Science Basis. Contribution of Working Group I to the Fifth Assessment Report of the Intergovernmental Panel on Climate Change. Cambridge, United Kingdom and New York, NY, USA.: Cambridge University Press, pp. 1217-1308.

Chylek, P. et al., 2012. Greenland ice core evidence for spatial and temporal variability of the Atlantic Multidecadal Oscillation. Geophysical Research Letters, 39(9), pp.1-6.

Chylek, P. et al., 2011. Ice-core data evidence for a prominent near 20 year time-scale of the Atlantic Multidecadal Oscillation. Geophysical Research Letters, 38(13), pp.1-5.

Cook, E.R. et al., 1999. Drought reconstructions for the continental United States. Journal of Climate, 12(4), pp.1145-1162.

Crowley, T.J., Obrochta, S.P. \& Liu, J., 2014. Recent global temperature 'plateau' in the context of a new proxy reconstruction. Earth's Future, pp.281-294.

D’Arrigo, R., Villalba, R. \& Wiles, G., 2001. Tree-ring estimates of Pacific decadal climate variability. Climate Dynamics, 18(3-4), pp.219-224.

D'Arrigo, R. \& Wilson, R., 2006. On the Asian expression of the PDO. International Journal of Climatology, 26(12), pp.1607-1617.

DelSole, T., 2017. Decadal Prediction of Temperature: Achievements and Future Prospects. Current Climate Change Reports.

England, M.H. et al., 2014. Recent intensification of wind-driven circulation in the Pacific and the ongoing warming hiatus. Nature Climate Change, 4(3), pp.222-227.

Farneti, R., Molteni, F. \& Kucharski, F., 2014. Pacific interdecadal variability driven by tropical-extratropical interactions. Climate Dynamics, 42(11-12), pp.3337-3355.

Folland, C.K. et al., 1999. Large scale modes of ocean surface temperature since the late nineteenth century. In A. Navarra, ed. Beyond El Niño: Decadal and interdecadal climate 
variability. Springer Verlag, pp. 73-102.

Folland, C.K. et al., 2002. Relative influences of the Interdecadal Pacific Oscillation and ENSO on the South Pacific Convergence Zone. Geophysical Research Letters, 29(13), pp.21-1-21-4.

Franke, J. et al., 2013. Spectral biases in tree-ring climate proxies. Nature Climate Change, 3(4), pp.360-364.

Frauenfeld, O.W. \& Davis, R.E., 2002. Midlatitude circulation patterns associated with decadal and interannual Pacific Ocean variability. Geophysical Research Letters, 29(24), p.2221.

Fyfe, J.C. et al., 2016. Making sense of the early-2000s warming slowdown. Nature Clim. Change, 6(3), pp.224-228.

Gallant, A.J.E. et al., 2013. Nonstationary Australasian teleconnections and implications for paleoclimate reconstructions. Journal of Climate, 26(22), pp.8827-8849.

Gedalof, Z., Mantua, N.J. \& Peterson, D.L., 2002. A multi-century perspective of variability in the Pacific Decadal Oscillation: new insights from tree rings and coral. Geophysical Research Letters, 29(24), p.2204.

Gedalof, Z. \& Smith, D.J., 2001. Interdecadal climate variability and regime-scale shifts in Pacific North America. Geophysical Research Letters, 28, pp.1515-1518.

Gergis, J. \& Henley, B.J., 2016. Southern Hemisphere rainfall variability over the past 200 years. Climate Dynamics.

Good, S.A., Martin, M.J. \& Rayner, N.A., 2013. EN4: Quality controlled ocean temperature and salinity profiles and monthly objective analyses with uncertainty estimates. Journal of Geophysical Research: Oceans, 118(12), pp.6704-6716.

Gouriou, Y. \& Delcroix, T., 2002. Seasonal and ENSO variations of sea surface salinity and temperature in the South Pacific Convergence Zone during 1976-2000. Journal of Geophysical Research-oceans, 107(C12).

Hawkins, E. \& Sutton, R., 2009. The Potential To Narrow Uncertainty In Regional Climate Predictions. Bulletin of the American Meteorological Society, 90(8), pp.1095-1107.

Henley, B.J. et al., 2015. A Tripole Index for the Interdecadal Pacific Oscillation. Climate Dynamics, 45(11-12), pp.3077-3090.

Henley, B.J. et al., 2011. Climate-informed stochastic hydrological modeling: Incorporating decadal-scale variability using paleo data. Water Resour. Res., 47(11), p.W11509.

Henley, B.J., 2012. Climate-Informed Stochastic Hydrological Modelling. The University of Newcastle, Australia.

Henley, B.J. et al., 2017. Spatial and temporal agreement in climate model simulations of the Interdecadal Pacific Oscillation. Environmental Research Letters, 12(4), p.44011.

Henley, B.J. \& King, A.D., 2017. Trajectories towards the $1.5^{\circ} \mathrm{C}$ Paris target: modulation by the Interdecadal Pacific Oscillation. Geophysical Research Letters, p.Accepted.

Henley, B.J., Thyer, M.A. \& Kuczera, G., 2013. Climate driver informed short-term drought risk evaluation. Water Resour. Res., 49(5), pp.2317-2326.

Hidalgo, H.G. et al., 2001. Comparison of tree species sensitivity to high and low extreme hydroclimatic events. Physical Geography, 22(2), pp.115-134.

Huang, B. et al., 2015. Extended reconstructed sea surface temperature version 4 (ERSST.v4). 
Part I: Upgrades and intercomparisons. Journal of Climate, 28(3), pp.911-930.

Juillet-Leclerc, A. et al., 2006. SPCZ migration and ENSO events during the 20th century as revealed by climate proxies from a Fiji coral. Geophysical Research Letters, 33(17).

Kirtman, B. et al., 2013. Near-term climate change: projections and predictability. In T. F. Stocker et al., eds. Climate Change 2013: The Physical Science Basis. Contribution of Working Group I to the Fifth Assessment Report of the Intergovernmental Panel on Climate Change. Cambridge, United Kingdom and New York, NY, USA.: Cambridge University Press, pp. 953-1028.

Knight, J.R. et al., 2005. A signature of persistent natural thermohaline circulation cycles in observed climate. Geophysical Research Letters, 32(20), p.L20708.

Kosaka, Y. \& Xie, S.-P., 2013. Recent global-warming hiatus tied to equatorial Pacific surface cooling. Nature, 501(7467), pp.403-7.

Kosaka, Y. \& Xie, S.-P., 2016. The tropical Pacific as a key pacemaker of the variable rates of global warming. Nature Geoscience, 9(9), pp.669-673.

Linsley, B.K. et al., 2015. Decadal changes in South Pacific sea surface temperatures and the relationship to the Pacific decadal oscillation and upper ocean heat content. , pp.1-9.

Linsley, B.K. et al., 2008. Interdecadal-decadal climate variability from multicoral oxygen isotope records in the South Pacific Convergence Zone region since 1650 A.D. Paleoceanography, 23(2), p.PA2219.

Linsley, B.K. et al., 2006. Tracking the extent of the South Pacific Convergence Zone since the early 1600s. Geochemistry, Geophysics, Geosystems, 7(5), pp.1-15.

Linsley, B.K., Wellington, G.M. \& Schrag, D.P., 2000. Decadal sea surface temperature variability in the sub-tropical South Pacific from 1726 to 1997 A.D. Science, 290, pp.11451148.

Liu, Z., 2012. Dynamics of Interdecadal Climate Variability: A Historical Perspective. Journal of Climate, 25(6), pp.1963-1995.

Lu, P., McCreary Jr., J.P. \& Klinger, B.A., 1998. Meridional circulation cells and the source waters of the Pacific equatorial undercurrent. Journal of Physical Oceanography, 28(1), pp.62-84.

MacDonald, G.M. \& Case, R.A., 2005. Variations in the Pacific Decadal Oscillation over the past millennium. Geophysical Research Letters, 32(8), p.L08703.

Maher, N., Gupta, A. Sen \& England, M.H., 2014. Drivers of decadal hiatus periods in the 20th and 21st centuries. Geophysical Research Letters, 41(May), pp.5978-5986.

Mann, M.E. et al., 2009. Global signatures and dynamical origins of the Little Ice Age and Medieval Climate Anomaly. Science (New York, N.Y.), 326(5957), pp.1256-60.

Mann, M.E. et al., 2007. Robustness of proxy-based climate field reconstruction methods. , 112.

Mantua, N.J. et al., 1997. A Pacific Interdecadal Climate Oscillation with Impacts on Salmon Production. Bulletin of the American Meteorological Society, 78(6), pp.1069-1079.

Mantua, N.J. \& Hare, S.R., 2002. The Pacific Decadal Oscillation. Journal Of Oceanography, 58(1), pp.35-44.

Marotzke, J. et al., 2016. MiKlip: A National Research Project on Decadal Climate Prediction. Bulletin of the American Meteorological Society, pp.2379-2394. 
Mauget, S.A., 2003. Multidecadal regime shifts in US streamflow, precipitation, and temperature at the end of the twentieth century. Journal Of Climate, 16(23), pp.3905-3916.

McGregor, S., Timmermann, A. \& Timm, O., 2010. A unified proxy for ENSO and PDO variability since 1650 . Climate of the Past, 6(1), pp.1-17.

Meehl, G.A., Hu, A., Santer, B.D., et al., 2016. Contribution of the Interdecadal Pacific Oscillation to twentieth-century global surface temperature trends. Nature Climate Change, 1(August 2016), pp.13-16.

Meehl, G.A. et al., 2014. Decadal climate prediction an update from the trenches. Bulletin of the American Meteorological Society, 95(2), pp.243-267.

Meehl, G.A., Arblaster, J.M. \& Chung, C.T.Y., 2015. Disappearance of the southeast U.S. 'warming hole' with the late 1990s transition of the Interdecadal Pacific Oscillation. Geophysical Research Letters, 42(13), pp.5564-5570.

Meehl, G.A., Hu, A. \& Teng, H., 2016. Initialized decadal prediction for transition to positive phase of the Interdecadal Pacific Oscillation. Nature Communications, 7, p.11718.

Meehl, G.A. \& Teng, H., 2014. CMIP5 multi-model hindcasts for the mid-1970s shift and early 2000s hiatus and predictions for 2016-2035. Geophysical Research Letters, 41(5), pp.17111716.

Meehl, G. a. et al., 2009. Decadal prediction: can it be skillful? Bulletin of the American Meteorological Society, 90(10), pp.1467-1485.

Meehl, G. a. \& Hu, A., 2006. Megadroughts in the Indian Monsoon Region and Southwest North America and a Mechanism for Associated Multidecadal Pacific Sea Surface Temperature Anomalies. Journal of Climate, 19(9), pp.1605-1623.

Minobe, S., 1997. A 50-70 year climatic oscillation over the North Pacific and North America. Geophysical Research Letters, 24(6), pp.683-686.

Mortazavi-Naeini, M. et al., 2015. Robust optimization to secure urban bulk water supply against extreme drought and uncertain climate change. Environmental Modelling and Software, 69, pp.437-451.

Newman, M. et al., 2016. The Pacific decadal oscillation, revisited. Journal of Climate, 29(12), pp.4399-4427.

Parker, D. et al., 2007. Decadal to multidecadal variability and the climate change background. Journal of Geophysical Research Atmospheres, 112(18).

Parker, D.E., Folland, C.K. \& Jackson, M., 1995. Marine surface temperature: observed variations and data requirements. Climatic Change, 31(2-4), pp.559-600.

Power, S. et al., 2016. Apparent limitations in the ability of CMIP5 climate models to simulate recent multi-decadal change in surface temperature: implications for global temperature projections. Climate Dynamics, pp.1-17.

Power, S. et al., 1999. Inter-decadal modulation of the impact of ENSO on Australia. Climate Dynamics, 15(5), pp.319-324.

Power, S. et al., 1999. Inter-decadal modulation of the impact of ENSO on Australia. Climate Dynamics, 15(5), pp.319-324.

Rayner, N.A. et al., 2006. Improved analyses of changes and uncertainties in sea surface temperature measured in situ sice the mid-nineteenth century: The HadSST2 dataset. 
Journal Of Climate, 19(3), pp.446-469.

Salinger, M.J. et al., 2014. A new index for variations in the position of the South Pacific convergence zone 1910/11-2011 / 2012. Climate Dynamics, 43(3-4), pp.881-892.

Schmidtko, S., Johnson, G.C. \& Lyman, J.M., 2013. MIMOC: A global monthly isopycnal upper-ocean climatology with mixed layers. Journal of Geophysical Research: Oceans, 118(4), pp.1658-1672.

Schneider, N. \& Cornuelle, B.D., 2005. The forcing of the Pacific Decadal Oscillation. Journal Of Climate, 18(21), pp.4355-4373.

Schneider, T., 2001. Analysis of incomplete climate data: estimation of mean values and covariance matrices and imputation of missing values. Journal of Climate, 14(5), pp.853871.

Schwarz, G., 1978. Estimating the dimension of a model. Annals of Statistics, 6(2), pp.461-464.

Shakun, J.D. \& Shaman, J., 2009. Tropical origins of North and South Pacific decadal variability. Geophysical Research Letters, 36(19), p.L19711.

Shen, C.M. et al., 2006. A Pacific Decadal Oscillation record since 1470 AD reconstructed from proxy data of summer rainfall over eastern China. Geophysical Research Letters, 33(3), p.L03702.

Smith, D.M. et al., 2016. Role of volcanic and anthropogenic aerosols in the recent global surface warming slowdown. Nature Climate Change, 6(10), pp.936-940.

Thomson, D.J., 1982. Spectrum Estimation and Harmonic-analysis. Proceedings of the IEEE, 70(9), pp.1055-1096.

Vance, T.R. et al., 2015. Interdecadal Pacific variability and eastern Australian megadroughts over the last millennium. Geophysical Research Letters, 42(1), pp.129-137.

Verdon, D.C. \& Franks, S.W., 2006. Long-term behaviour of ENSO: Interactions with the PDO over the past 400 years inferred from paleoclimate records. Geophysical Research Letters, 33(6), p.L06712.

Vincent, D.G., 1994. The South-Pacific Convergence Zone (SPCZ) - A Review. Monthly Weather Review, 122(9), pp.1949-1970.

Wang, C. et al., 2012. El Nino and Southern Oscillation (ENSO): A Review. In Coral Reefs of the Eastern Pacific. Springer.

Westra, S., Renard, B. \& Thyer, M., 2015. The ENSO-precipitation teleconnection and its modulation by the Interdecadal Pacific Oscillation. Journal of Climate, p.150327084951005.

Wilks, D.S., 2010. Sampling distributions of the Brier score and Brier skill score under serial dependence. Quarterly Journal of the Royal Meteorological Society, 136(653), pp.2109-2118.

Zhang, D., Li, X. \& Liang, Y., 2003. Supplement of yearly charts of dryness/wetness in China for the last 500-year period, 1993--2000. J. Appl. Meteorol. Sci., 14, pp.379-389.

Zhang, Y., Wallace, J.M. \& Battisti, D.S., 1997. ENSO-like interdecadal variability: 1900-93. Journal Of Climate, 10(5), pp.1004-1020.

\section{Acknowledgments}

BJH is funded by an Australian Research Council Linkage Project LP150100062 with The University of Melbourne, Melbourne Water, the Victorian Department of Environment, Land, 
949 Water and Planning, the Australian Bureau of Meteorology and Monash University. The 950 author would like to acknowledge the advice and discussions with Dr Andrew King, Prof 951 David Karoly and Dr Leela Frankcombe during the development of this article. He also 952 thanks the two anonymous reviewers for their detailed, considered and informed reviews of 953 this article. 